The Public Journal of Semiotics II(2), July 2008, pp. 73-102

\title{
The spatial dimension of history: propagation of historical knowledge via open-air museums, leisure parks and motion pictures
}

\author{
Ulf Ickerodt \\ Vor- und Frühgeschichtliche Archäologie \\ Dept. für Kulturgeschichte und Kulturkunde der Universität Hamburg \\ Edmund-Siemers-Allee 1, West D - 20146 Hamburg \\ U.Ickerodt@web.de
}

\begin{abstract}
Man's environment is full of references to history. Archaeological sites and cultural landscapes are examples. History is a constituent of our social identity. In this sense, on a social level, it has an integrating function and helps to structure and canalize social behaviour. In this paper we shall examine, taking archaeological sites, open-air museums, leisure parks and motion pictures as examples, how this form of promotion of history works and what effect it has on society.
\end{abstract}

Keywords: progress thinking, history promotion, space \& time perception, social identity, sociology \& ethics of science

\section{Introduction}

The propagation of archaeological knowledge via staged archaeological sites, open-air museums, leisure parks and films makes use of a reconstructed archaeological/historical environment.

While designing such places, one is trained to concentrate on the "in-situ" quality of the site in order to provide the public with a feeling for the original site documented by archaeological fieldwork. Recent examples include the Viking settlement of Haithabu in northern Germany (Schleswig-Holstein) (Ickerodt 2007:269 Fig. 4), where more reconstructions of the original buildings are being erected, and the Hahnenkooper-Mühle, a Bronze Age long-house at Rodenkirchen, Lower Saxony (Ickerodt 2007:269 Fig.5), as well as the reconstructions of Stone Age dwellings at the Hitzacker Archaeological Centre (Archäologischen Zentrum Hitzacker), Lower Saxony.

Implicitly, the archaeological world assumes that the significance of the information and knowledge gathered by research and fieldwork can be put over to the public by means of these sites, sometimes combined with the activities of reenactment groups. There is a common belief that our archaeological/historical background can be divided up in order to provide historic insights to the visiting public. The self-chosen indicator of quality of these exhibits is their degree of authenticity. And a central aspect throughout is the conviction that the archaeological/historical facts are self-evident.

In addition, one should take into account that "history" can only be generated from a string of historical facts by knitting them together into a narrative. Such 
meta-narratives ${ }^{1}$ dealing with the different facets of history ${ }^{2}$ are the vehicles that make historical understanding possible. Such a meta-narrative, mythologically or scientifically legitimated, is always a social construction which makes use of historically evolved and socially accepted structures. These meta-narratives help each individual person, depending on their individual degree of perception, i.e. their learned ability to understand place-time relations to generate social and individual behaviour. This process must be understood as being based on past experience and oriented on future aims; socially inherited perception is combined with personal experience of life. This complex of preexisting (i.e. inherited) social "guidelines" and the way each individual interprets his own environment in fact determines our perception of historical facts: It steers (1) our selection of historical facts, (2) the evaluation process with respect to their plausibility, and (3) it enables us to crosslink historical events, episodes etc. into an overall system.

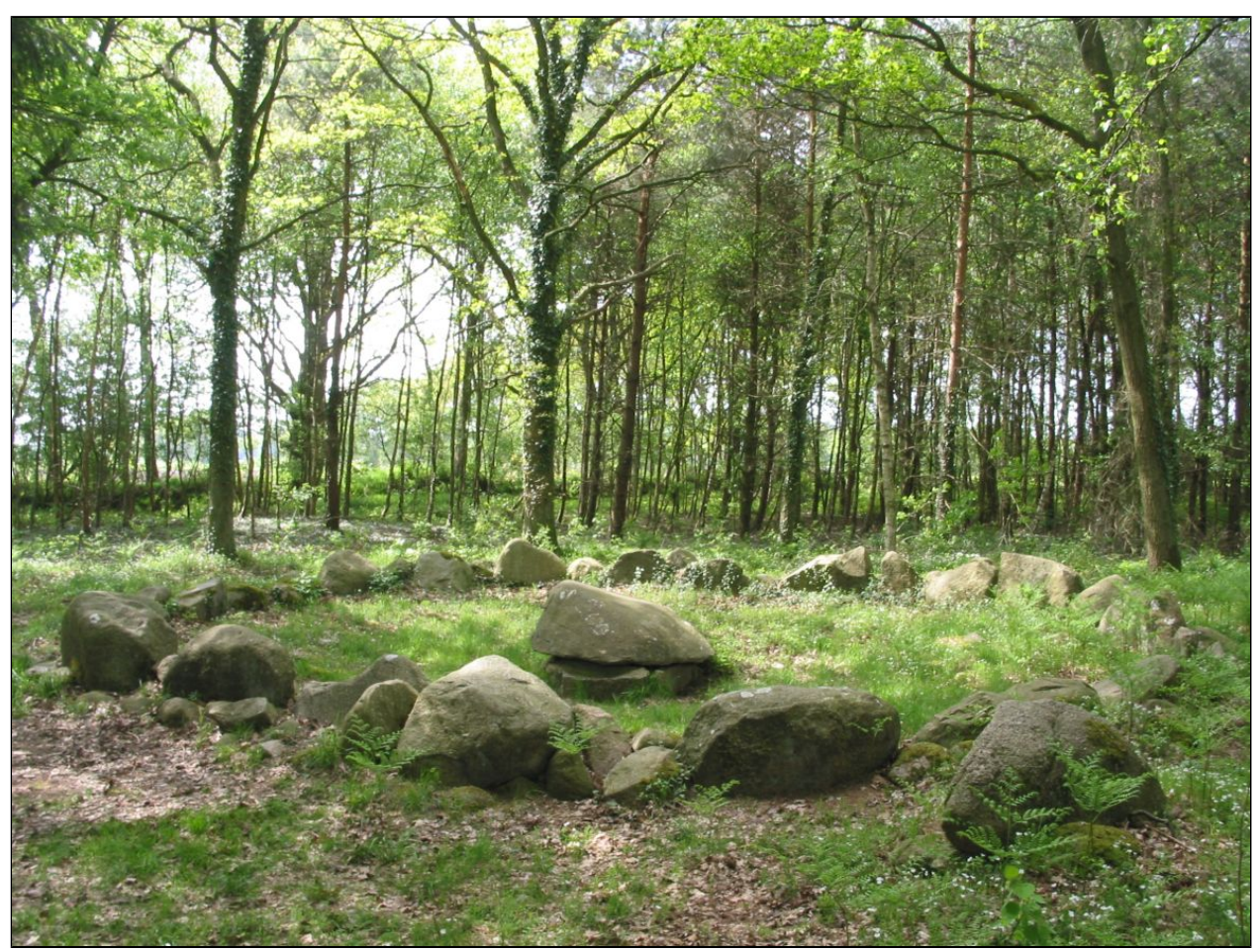

Figure 1. The megalith site of Flögeln as an example of an archaeological site made accessible to the public (photo by the author).

In this connection it is crucial to realize that the understanding of an overall historical system and/or of its single parts depends on one's own group affiliation. This affiliation allows one to correlate historical evidence and relics into a meaningful and reasonable overall system or, in contrast and as an extreme example, it precludes the understanding of archaeological/historical facts.

\footnotetext{
${ }^{1}$ These are the meta-narratives in the sense of $\mathrm{H}$. White (1973; 1996), which can be understood in the sense of a founding myth.

${ }^{2}$ History of technology, local, regional and world history, and the history of mankind.
} 
Therefore it seems apt to split the perception and understanding of history into two modes of perception. The basic mode is a socially anchored mode of perception. It is closely related to society's construction of reality and is learned unconsciously during one's life. It is the product of a historical process, which is normally unaffected by active social control, even if sometimes it can be consciously steered. The second mode of perception is a more distinct, one could say an analytical, form dealing with place-time relations. Both modes of perception are individually and socially anchored, are interactive, and can only be separated from each other analytically. Such an overall perception forms an essential component of one's own local, regional and national identity.

These preliminary remarks lead us to the topics to be dealt with: (1) How is archaeological knowledge embedded in socially generated historical understanding and how does this influence scientific knowledge and thinking? (2) How must archaeological information be processed to make it understandable to the layman? And lastly concerning the social influence of archaeology: (3) What are the responsibilities of the archaeological community?

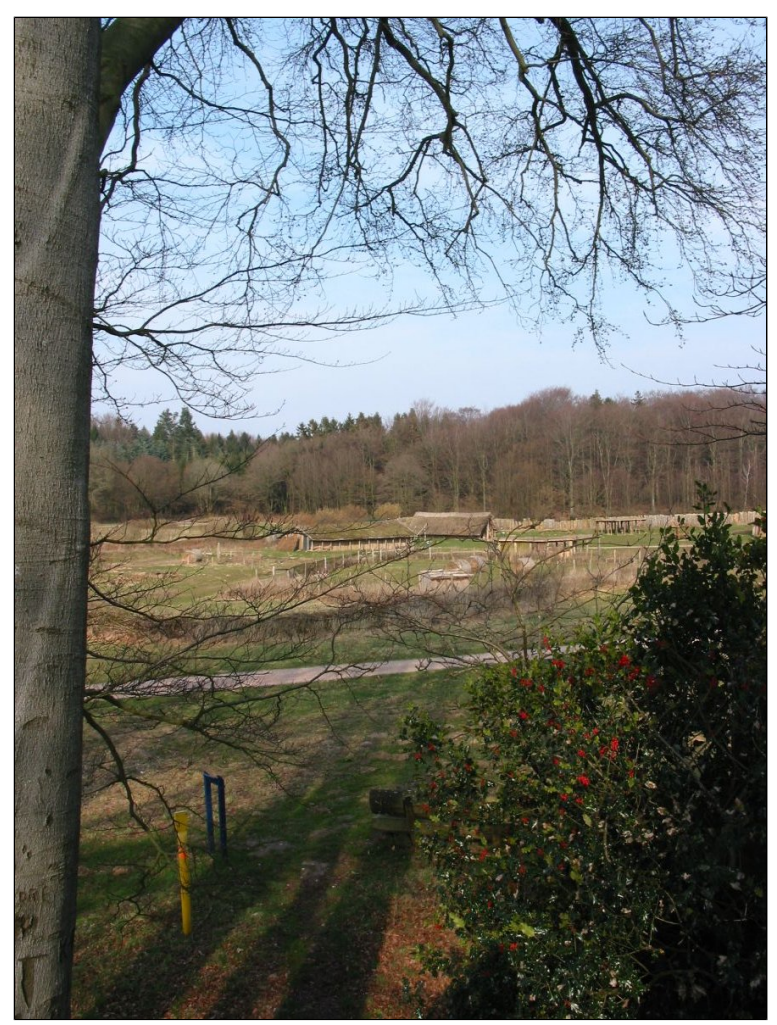

Figure 2. View of the reconstructed Neolithic settlement and landscape at the Archäologisch-Ökologisches Zentrum Albersdorf (AÖZA) (photo by the author).

These questions pose further questions concerned with the philosophy of science and its two domains, the sociology of science and the ethics of science.

Generally speaking, the sociology of science helps us to understand how archaeological research is embedded in society and the basic preconditions necessary for its incorporation. Research on the sociology of science, in this case ar- 
chaeology, is not only concerned with the history of archaeological research and thinking, but also deals with its social acceptance, as well as the determining influence of the social environment on archaeology as a discipline. In this sense, the sociology of science encompasses the self-reflexive process of establishing one's own scientific understanding as well as generally accepted plausibilities. Such an approach allows a basic process of self-criticism in terms of methods, theories and interpretation patterns beyond the individual case. It helps to ensure quality in the long-term.

However, at the same time, the sociology of science deals with the influence of archaeological knowledge on social mentality in terms of the social incorporation of archaeological research by society as well as in terms of the social treatment of archaeological data. From the perspective of content, the archaeologist deals with the social and sub-cultural processes of how historical narrations become established. On a practical level, such an approach serves to ensure quality in the process of propagation of archaeological/historical knowledge in the sense of didactics of archaeology.

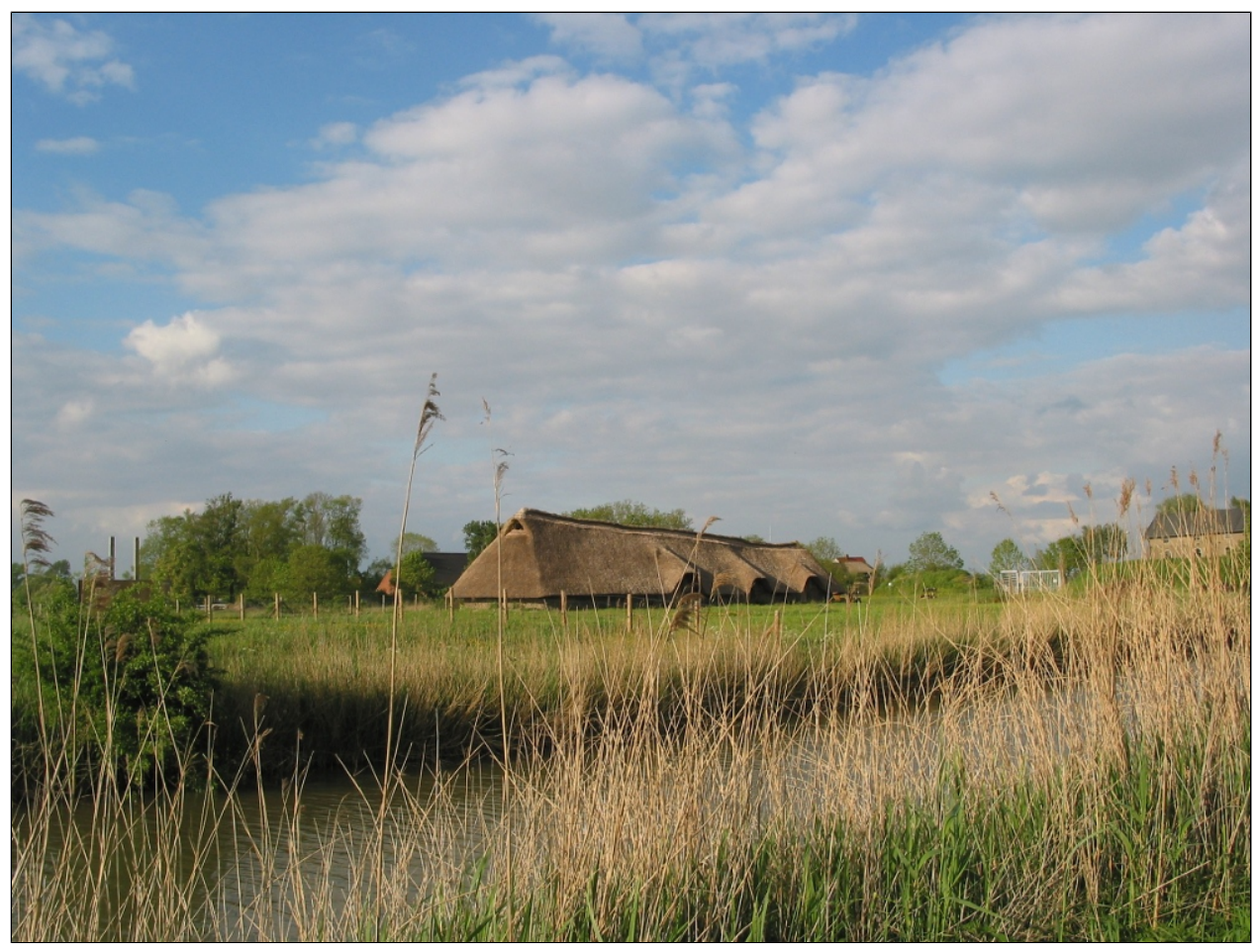

Figure 3. Reconstructed Bronze Age dwelling at Rodenkirchen, Hahnenkooper-Mühle (photo by the author).

On a more abstract level, the sociology of science helps archaeology to understand the surrounding social environment, which has a major influence on archaeological research, in terms of structure and content. This knowledge is a necessary tool for research on the second topic, the ethics of science.

To attain a truly scientifically based didactics of archaeology, one needs to take the first basic step of assuring one's self of one's own social environment in order 
not to abandon scientific facts in favour of cultural arbitrariness but to promote truly archaeologically/historically based knowledge.

\section{$2 \quad$ Founding myth and historical thinking}

In our science-based society, myths and superstitions are commonly percieved and communicated as a primitive form of thinking belonging to the dawn of mankind. Even when myths ${ }^{3}$ are touched on, they appear at the same time to be suppressed from our seemingly logos-based daily life. The philosopher Emil Angehrn (1996), in his analyses „Ursprungsmythos und Geschichtsdenken" (Founding myth and historical thinking), comes to the conclusion that this antonymic relationship between logos and mythos does not exist because of the fusion of myth and science within metaphysics. This hidden relationship between myth and logos is normally not taken into consideration by scientific research and its incorporation by society. Sometimes it is not even seen. Nevertheless, the mystification of archaeological knowledge is commonly used as a appropriate medium to escape from technicist ratio within a secularised society ${ }^{4}$.

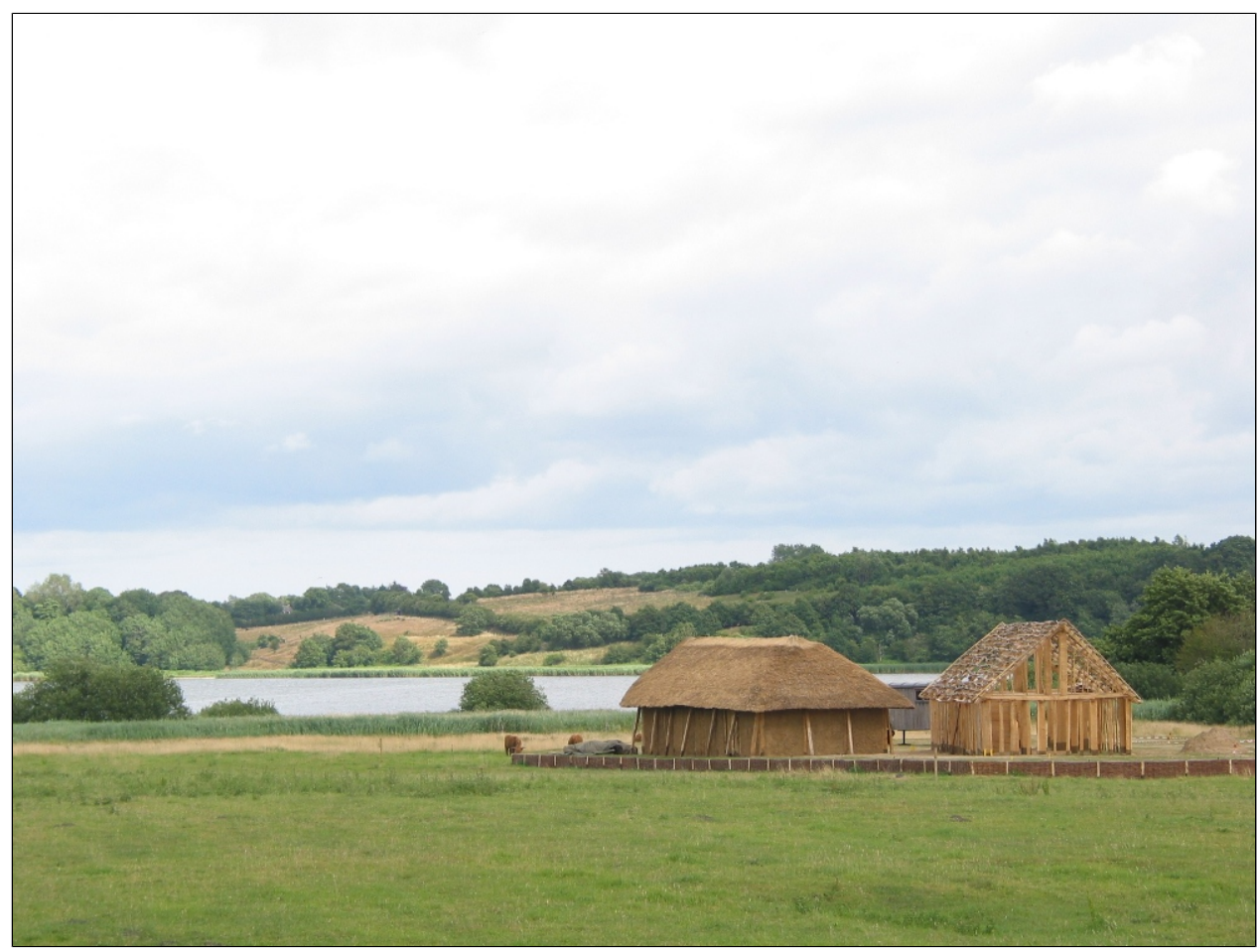

Figure 4. Reconstructed Viking settlement of Haithabu associated with the Schleimündung nature-conservation area (photo by the author).

\footnotetext{
${ }^{3}$ The horror novels of H.P. Lovecraft (1890-1937) (Mosig 1997) are good examples of the social process of myth creation in modern times based on scientific knowledge and dealing with the beginning of mankind in the cosmos.

${ }^{4}$ This phenomenon has been referred to as an "ersatz-enchantment" (Ickerodt 2004a:54, 172ff. see also Ickerodt 2005a).
} 
While examining the relationship between myths and archaeological/historical research against this background, both can be identified by their content as a form of the reflection of one's own origins. Both are, generally speaking, elements of man's ability to deal with his origin and, on a more specific level, to pass on experience of the past to forthcoming generations. Mythologically and historically legitimated forms of thinking have, in different ways, a self-constituting and legitimating function. They explain how our world has become the place that it is today. In this way, both may legitimate social institutions and social behaviour. They help to stabilize man's existence and provide legal security. "Die Verwurzelung in der Herkunft ist eine Strategie der Identitätssicherung. Wer weiß, woher er kommt, weiß, wer er ist."5 (Angehrn 1996:307)

At the same time Angehrn (1996) sees, apart from recognising one's own origins, a second property characteristic of the mythos. As far its social function to provide a social identity and assure existence is concerned, the mythos has if necessary the ability to question its own origin, to break free from traditional structures and conventions ${ }^{6}$ that have become obsolete, and to replace them by newly created traditions (Ickerodt 2005a). This same effect has been discussed elsewhere (Ickerodt 2004a:185) in relation to pictures of prehistoric man. Prehistoric man has in fact become an icon for one's own origins. As our primitive ancestor he provides identity within the realm of the continuity-paradigm ${ }^{7}$. He is therefore, as mentioned above, an ambiguous figure. Not only does he provide an identity, but also he is used as a powerful but symbolic argument within the process of social differentiation on a society level as well as on a national level. On one hand, prehistoric man is a symbol of one's own roots, but on the other hand, on a more symbolic level and based on the concept noncontemporaneous contemporaneity, he is a symbol for social competition. Basically, the image of prehistoric man oscillates between a founding hero and primitive obstructer of social, economic and technological progress.

Following on from these ideas, it is aimed to show the social impact of archaeological knowledge as imparted by archaeological sites made accessible to the public, and in open-air museums, leisure parks and motion pictures.

\section{Research target: historical landscapes in open-air museums, leisure parks and motion pictures}

The environment that surrounds us, seen not only from a scientific perspective, is full of historical features and relics. As an archive it contains evidence of geological transformation and biological and cultural evolution. In this context, space, with all its historical information, can be seen as the spatial dimension of history.

\footnotetext{
5 “Recognising one's own origins is a strategy to secure identity. Who knows where he comes from or who he is?" (translation by the author)

${ }^{6}$ In this connection a cybernetic model of historical understanding has been developed that is based on evolutionary premises (Ickerodt 2006).

${ }^{7}$ In Germany the archaeologist Gustav Kossinna (1858-1931) developed the method of "ethnische Deutung" (ethnic interpretation) as a bourgeois method of self-assurance; meanwhile in the United States the "direct historical approach" was developed as a comparable method to investigate within the same scientific rational the roots of the American aboriginal societies.
} 
It is not only an archive, but at the same time the locality of historical teaching as initiated for us by Petrarca (1304-1374).

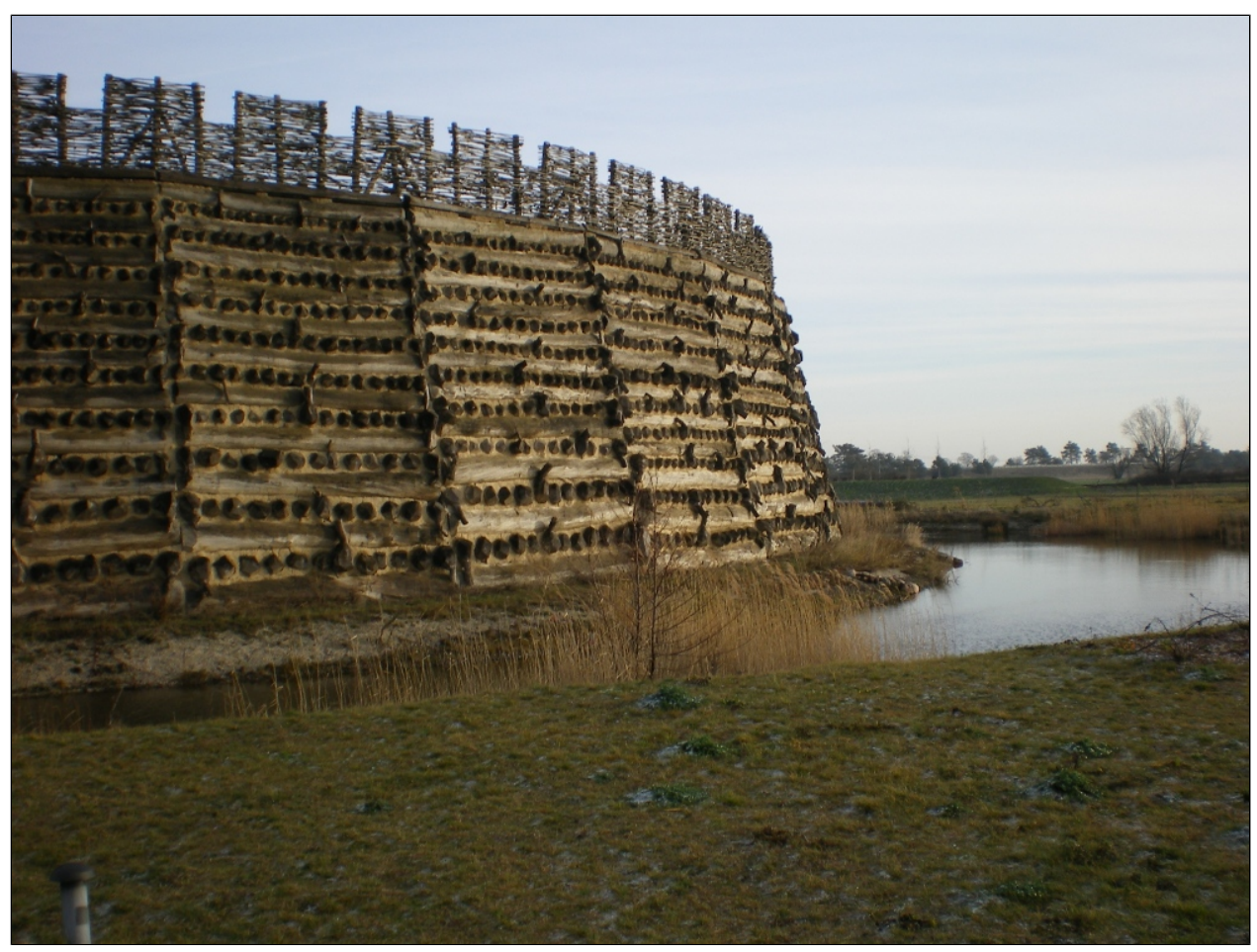

Figure 5. Reconstructed Slav castle of Raddusch (photo by the author).

At that time ruins were seen by Petrarca as monuments that were perishable (Böhme 1989; Ickerodt 2007), while in the second half of the 19th century this form of spatial-history narration is supplemented by a further aspect related to the name of Heinrich Schliemann (1822-1890). The public became increasingly aware of the fact that apart from the visible ruins, localities known from the bible, or that are historically documented, still remain as archaeological sites and thus can be referred to as historical evidence (Ickerodt 2004a). This awareness supplements the interpretation of landscapes-with-ruins in the sense of "perishable" monuments by two aspects. On one hand ruins are evidence of one's own beginnings and on the other hand they are used within social competition as evidence of the treat of cultural regression (Ickerodt 2004b).

The spectrum of the archaeological/historical landscapes that are part of this research (Table 1) comprises archaeological sites made accessible to the public, as well as reconstructed dwellings and other structures based on archaeological evidence which are located in open-air museums, leisure parks or used in motion pictures.

They can be divided on the basis of their characteristics into two categories each with two sub-categories: (1) authentic archaeological/historical sites with (1a) original material, and (1b) in-situ reconstructions based on the archaeological record, and in contrast, (2) fictitious archaeological/historical sites, only authentic by virtue of their content. Examples of (2) are reconstructed dwellings that have been identified on archaeological sites elsewhere. In contrast to (1) 
therefore, there is no historical reference to the locality chosen for presentation. (2) comprises two sub-categories: (2a) proven archaeological/historical sites, and (2b) chosen sites inspired by but unrelated to archaeology.

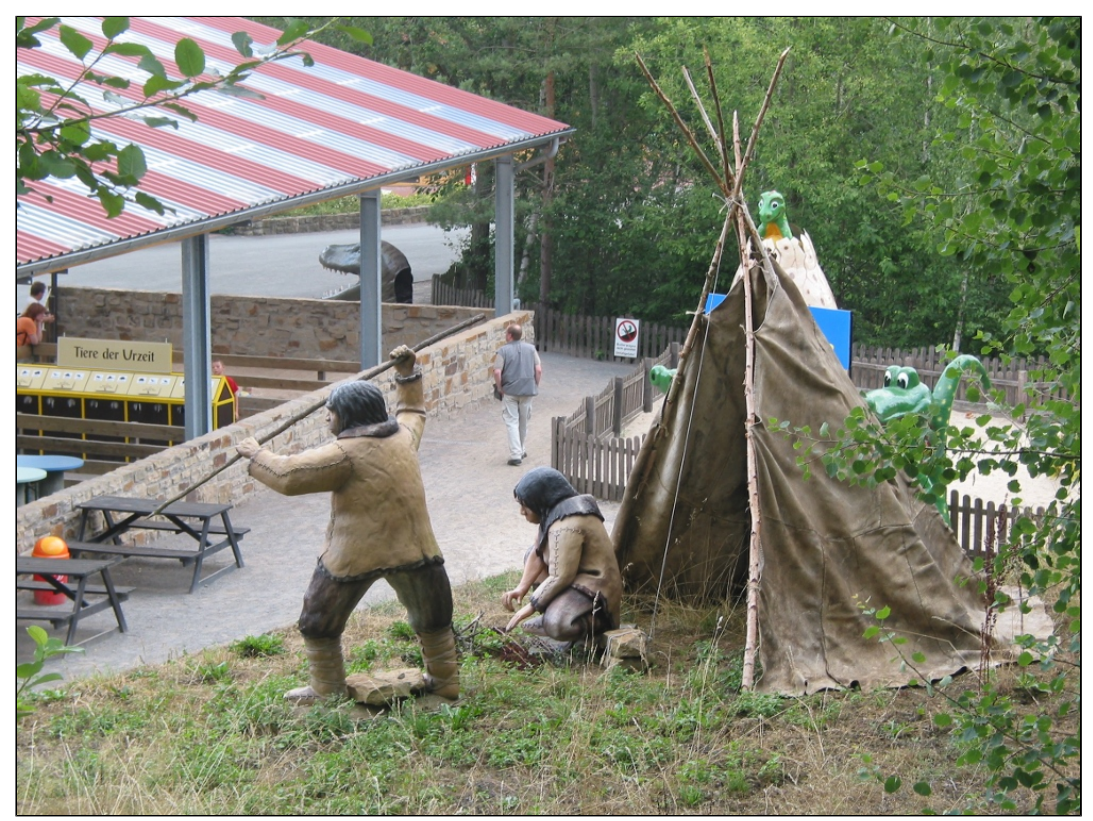

Fig. 6: At the Dino Park in Münchehagen (Lower Saxony, Germany) with its authentic fossil dinosaur tracks one can see scientifically inspired life pictures of Neanderthal man in front of their tent.

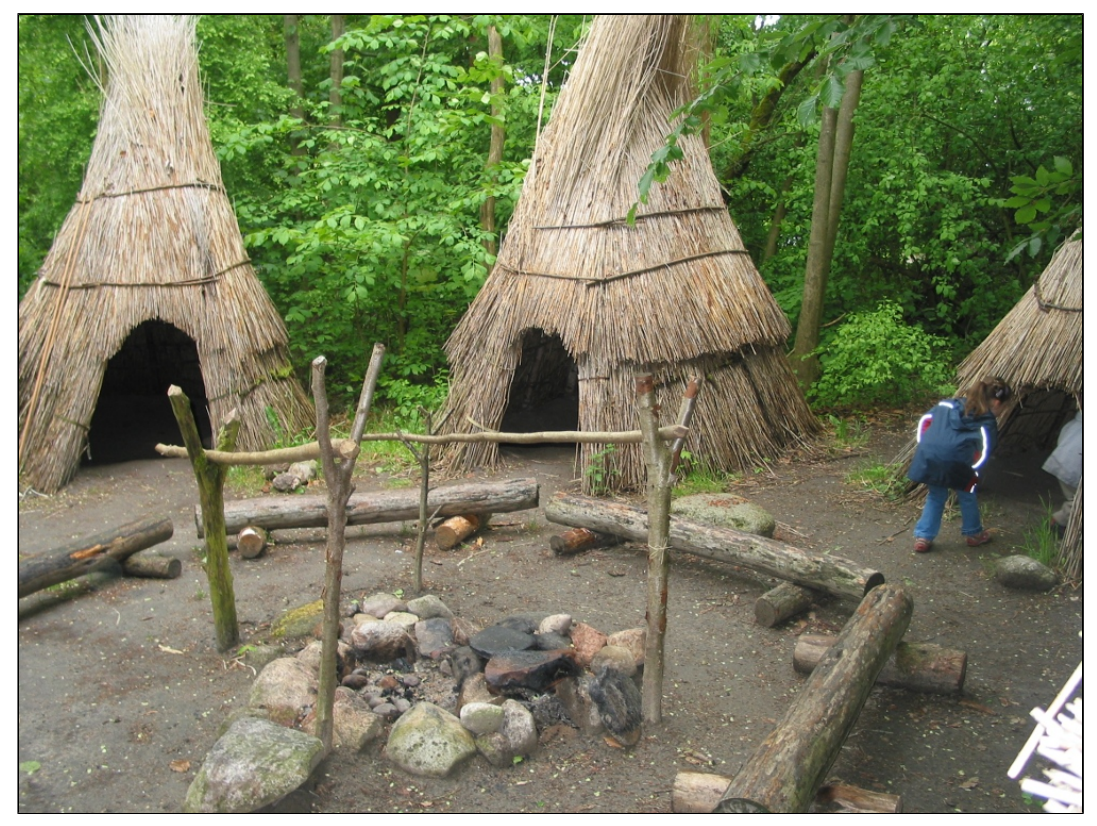

Figure 7. The Natureum in Neuhaus (Lower Saxony, Germany) has a scientifically inspired camp of prehistoric man, which is located in a small clearing and is made accessible along a narrow path in the plant cover (photo by the author). 
Category (1a) authentic archaeological/historical sites with their original substance, is commonly an output of archaeological fieldwork and the relevant public relations work. It is usually well accepted by an archaeologist to use "his" archaeological site as a tourist attraction ${ }^{8}$ (Fig. 1), since it promotes his own research; in case of a motion picture or in fiction, an archaeological site may be used as an "authentic" backdrop". The time scale ranges from the Neolithic to the Middle Ages.

Category (1b), reconstructed dwellings based on the archaeological record at the original site (Figs. 2 to 5), as well as (2a) the fictitious, scientifically proven or (2b) inspired archaeological/historical sites (Figs. 6 to 9) are quite comparable to the first group. Their time scale ranges from the Palaeolithic to the Middle Ages.

While in the above cases the visitor can approach the past by aesthetic means, whereby archaeological knowledge is imparted via the emotions, this approach must be seen against the background of the ethics of science.

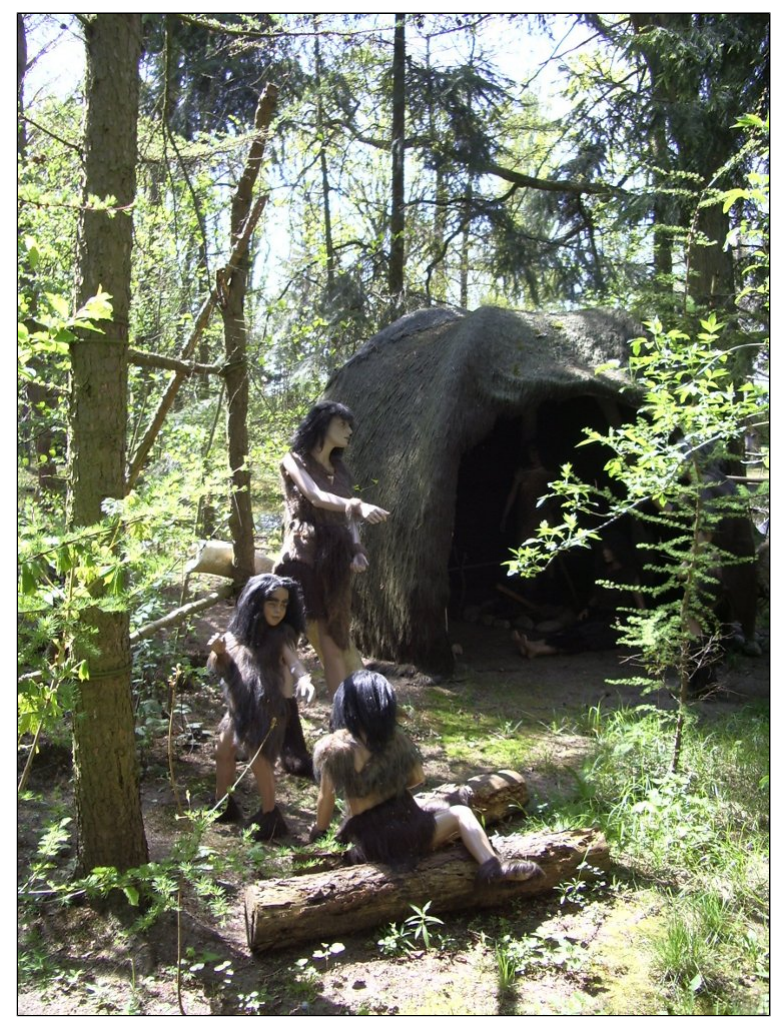

Figure 8. At the Erse leisure park in Uetze (Lower Saxony, Germany) one can view a scientifically inspired prehistoric environment (photo by the author).

\footnotetext{
${ }^{8}$ Examples of northern Germany: Ahrens (1976), Alsdorf (1980), Bärenfänger (1999), Führer zu vorund frühgeschichtlichen Denkmälern (1976 a to c), Hesse (2003), Lauer (1979; 1983; 1988), Schön (1995), Sielmann (1975), Zeitspuren 1998. Examples of Austria: Bichl, Griebl, La Speranza, Reisinger (2003); Examples of megalith sites: Bock, Fritsch, Mittag 2006, Burl 1995, Gottwald 1991a, Gottwald $1991 b$.

${ }^{9}$ For example "Tea with Mussolini” (USA 1999), “The match-maker” (USA 1997).
} 


\subsection{Case study: the reconstruction of Jamestown}

An especially influential medium for imparting archaeological knowledge is through motion pictures. Examples from recent years are Mel Gibson's "Apocalypto" (USA 2006) and Wolfgang Petersen's "Troy" (USA 2004), which were incidentally both enormous box-office successes. In the first case Gibson sets the plot and his fictitious reconstruction of the past in pre-Columbian Meso-America shortly before the arrival of the first Europeans. He depicts a cruel archaic world ruled by the struggle for life and the survival of the fittest. His reconstructed urban settings are extremely noteworthy on account of their strong visual effect, providing the spectator with a far-ranging insight into the life of the ancient Maya. On the other hand there is Petersen's film adaptation of the Trojan war, which, in spite of its recognizable adaptation of actual archaeological knowledge, is somewhat overinterpreted.

A totally different example can be found in Terence Malick's motion picture "The New World", which is set in the early 17th century at that point of time when the first English colony in North America was founded. Malick aims at the ultimate in authenticity and makes the film look as if it were a documentary film. William Kelso, Director of Archaeology at the Association for the Preservation of Virginia Antiquities, was invited as consultant. He saw his advice and his vision of the reconstruction of Jamestown widely implemented.

The film-set with modern technical equipment was erected by Jack Fisk, the production designer, in cooperation with his archaeological consultants within 30 days no further than 7 miles from the original location. Here, as well as in the case of the reconstructed native American settlement and the associated fields of crops, one was very concerned to achieve the highest possible degree of authenticity. Apart from using archaeological data, the producer utilised historical pictures and native American consultants. Furthermore, when possible, only local raw materials were used and in the case of the reconstructed native American fields one was very careful to use historical cultivation methods as well as original seed (maize, melons, tobacco, etc.)

While shooting, the actors and the crew felt as if they were time-travelling. This experience and the process of social reassurance is articulated on the associated DVD in interviews with the film-staff and actors. Each of them, regardless of their own origin, was really concerned with portraying their Anglo-American or native American roots, from which modern North America evolved.

\subsection{Case study: Time pathways}

Apart from the general process of historical recollection ("Where do I come from?"), the staged authentic archaeological/historical park with its (1a) original substance or $(1 \mathrm{~b})$ reconstructions based on the archaeological record, are commonly accompanied by a time axis. This time axis can be related to historic data or may be just a symbolic way of putting over cultural evolution. In both cases, it is just a practical tool to give the visitor a feeling for chronology as he walks along a time-line. Examples of such a time axis related to absolute data can be found at the Slav castle of Raddusch (Fig. 10) and the Neanderthal Museum at Mettmann (Fig. 11). 


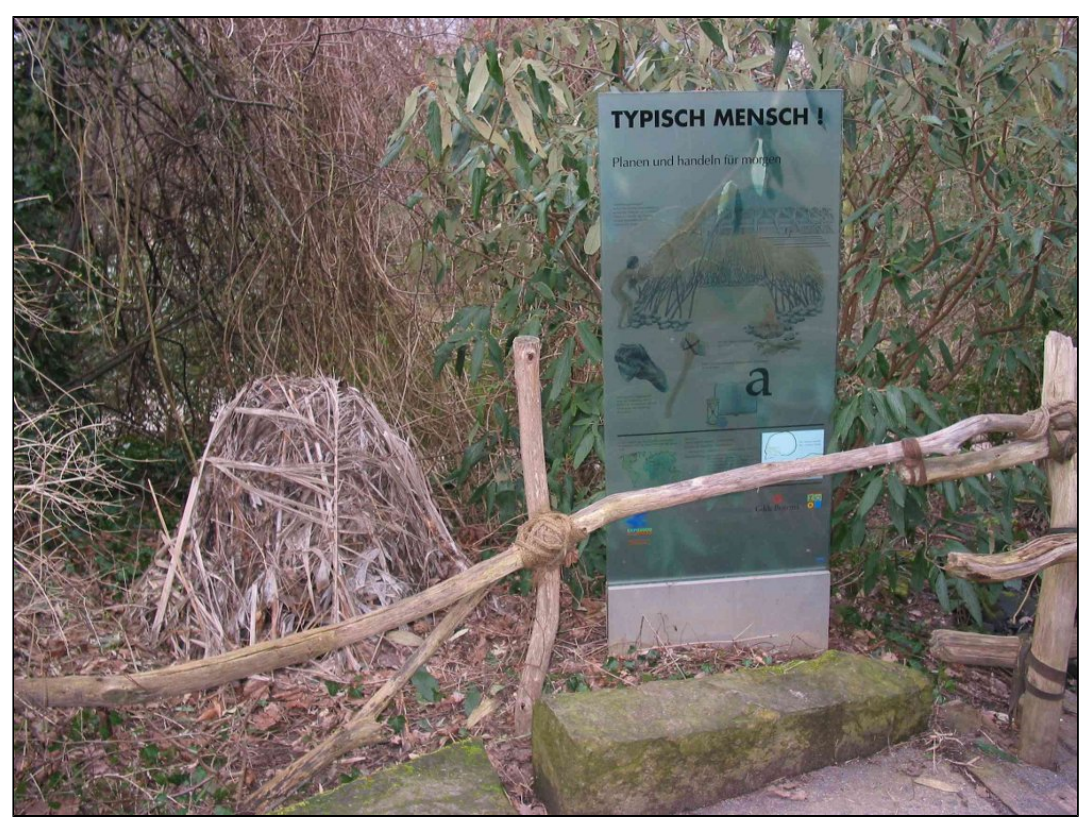

Figure 9. At the Erlebniszoo Hannover (Lower Saxony, Germany) the reconstruction of a prehistoric dwelling is situated near the pathway of evolution (photo by the author).

Here, as well as in the scientifically (2a) proven or (2b) inspired archaeologi$\mathrm{cal} /$ historical sites, one may also find the symbolic alternative of such a timepathway as a medium to impart human biological or cultural evolution. An especially interesting example can be found at the ErlebnisZoo Hannover (Hanover Experience Zoo). Here, footprints are used to represent human biological and cultural evolution. In a section called the "Path of Evolution" (Evolutionspfad), one can see footprints, inspired by the Laetoli tracks of East Africa (Fig. 13b) which turn uphill into footprints of soles of shoes (Fig. 13a). The shoe prints end at an excavation, symbolizing the search for human origins. A look back over one's shoulder seems to demonstrate man's social and scientific progress. This concept is based on simple teleological logic (Ickerodt 2004a: 49f.; Cat.7.2.) dominated by (mostly hidden) social Darwinist assumptions: Things are the way they are because they succeeded in competition (Ickerodt 2004b).

\subsection{Case study: Footprints and Tracks}

In order to make the last statement more comprehensible, one has to contemplate the iconographic meaning of footprints and tracks. Seemingly, they have been held as highly significant since the time of primitive man. On a very practical level, prehistoric hunters certainly used them to read the past in the present in order to make decisions for the future. With his knowledge of his own environment, the hunter could analyse the tracks and could predict vital information: Where can I catch my prey? Where do I expect predators? 


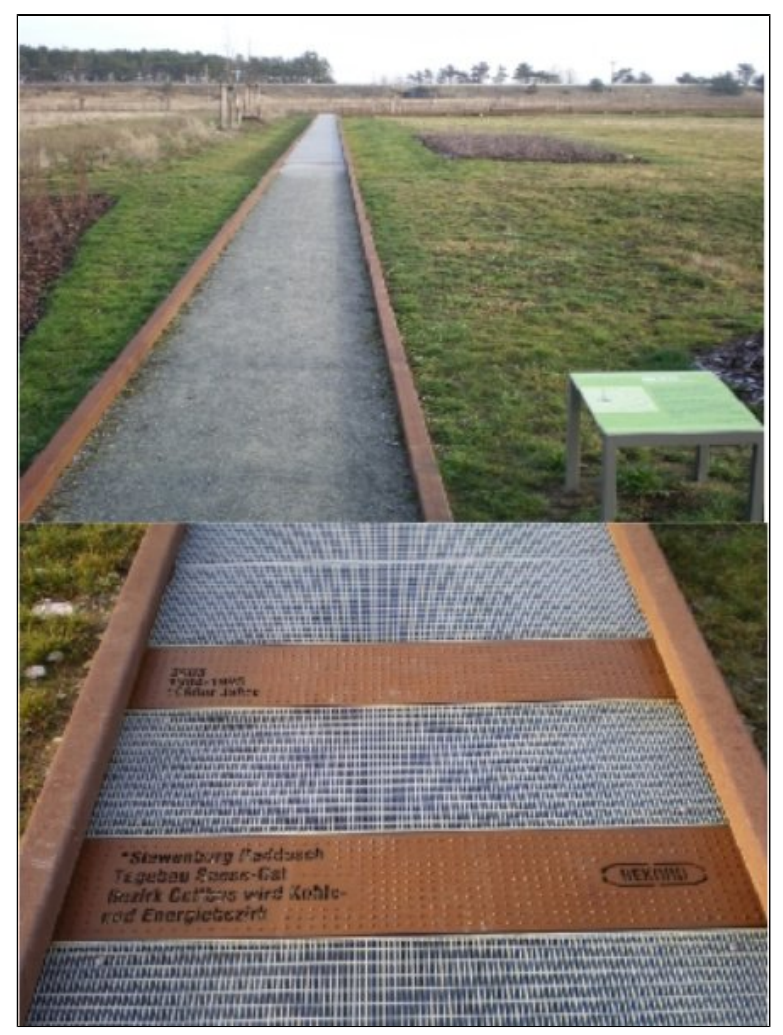

Figure 10. At the entrance of the Slav castle of Raddusch is situated the so-called "time plank" (above). Inscriptions provide a chronological framework (below) (photo by the author).

His ability to read and understand footprints and tracks made it possible to pursue his prey and avoid predators. Such a process of historical reflection allowed prehistoric man to contemplate the way he had covered and, on a more abstract level, to reflect his life-history. On this more elaborate level, the ability to interpret tracks could now be fitted into more and more complex interpretation patterns, to help to structure future behaviour.

All in all, it is no wonder that human tracks have a very special meaning and are culturally deeply anchored (Ickerodt 2004a:100f.; 2004b:13-16.) so that even contemporary advertisements can use the picture of footprints or tracks as a proof or a symbol for one's own existence and path of life and, on the other hand, as a metaphor for goals that one aims to reach (Ickerodt 2004a: Cat. 3.2.). But the metaphor of footprints and tracks has a second meaning. In a figurative sense footprints symbolize the process of detection. Archaeologists as well as detectives are constantly searching for "suspicious" features and clues.

It is not by chance that this combination of evolutionary tracks, footprints and an excavation are used in the ErlebnisZoo Hannover. Here is the place where the visitor can achieve his "incantation of origins". In a practical and simple way he is enabled to recognize the order of things and events and assure himself of the functionality of cosmic order. The look back verifies his own place in the world 
and confirms social and scientific/technological progress. This process is based on the teleologic concept mentioned above (Ickerodt 2004a: 49f.; Cat.7.2.).

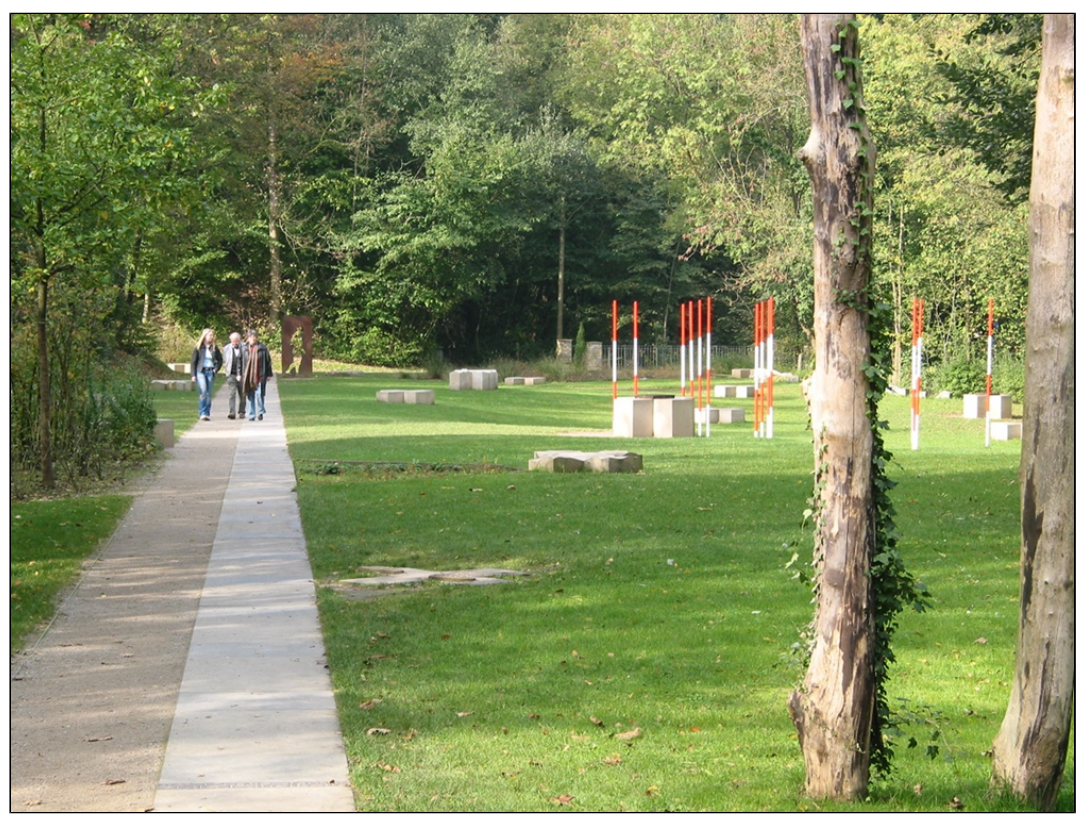

Figure 11. Close to the site where the Neanderthal remains were discovered at Mettmann, the chronological dimension is put over by the so called space-time axis (photo by the author).

This symbolic representation of human evolution, well known from "2001 A Space Odyssey" (GB 1968), can be found in a more condensed form at Mettmann. Within the area of the site where the Neanderthal remains were found, one can recognize a variation of this motif. Near the space-time axis here, is a cross made of concrete on which human (bare) footprints are crossed by footprints of an astronaut's boot as left on the moon (Fig. 12).

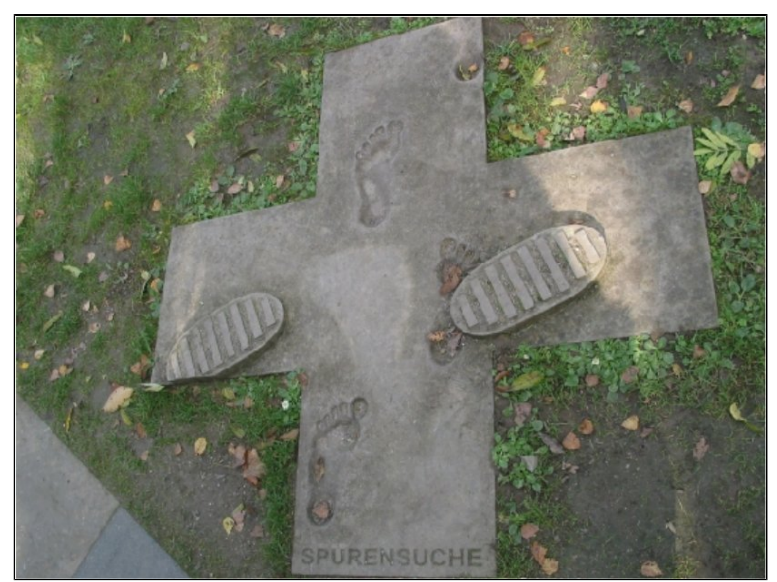

Figure 12. At the Neanderthal Museum is a cross made of concrete on which human (bare) footprints are crossed by footprints of an astronaut's boot as left on the moon (photo by the author). 
The same metaphor is used by the organizers of the exhibition "Roots / Wurzeln der Menschheit" (Roots / Origins of mankind) that could be viewed between 8 July and 19 November 2006 at the Rheinisches Landesmuseum (Rhenish Federal Museum), Bonn. One could follow a track of human Laetoli footprints leading to the exit where they changed into moon-boot prints in front of a moon landscape.

This is the way fossilized human remains, artefacts, archaeological sites, reconstructions in open-air museums, leisure parks, motion pictures and dioramas are organized for the layman within a context of progress thinking, which is in fact well known since it can be found in a comparable form in contemporary advertisements (Ickerodt 2004a: Cat.7.2 Nr. 9-15; 2004b:14 esp. footnotes 8 \& 9) and in motion pictures ${ }^{10}$.

\section{The "big" narrative: meta-narrative development thinking}

The initial point in understanding the social incorporation of archaeological research results and knowledge is the great chain of being, a special European form of understanding time as linear-progressive and in terms of continuity. This conception of time is distinguishable from cyclical time concepts used in other societies. Thereby we must consider that on the individual level, as well as within our own social environment, on one side there are numerous different interpretation patterns and readings as to what linear-progressive time is. On the other hand, the cyclical conception of time may still exist, or may be re-invented. Nevertheless, in the western world linear-progressive time conceptions are the main, widely accepted trend. The chief reason for this is that it is scientifically verifiable via the physical sciences, geology, biology and archaeology ${ }^{11}$ and it has demonstrated its suitability for daily use.

Seemingly, the main influence of linear-progressive time conception derives since its introduction from the theory of evolution, because of its increasing use within metaphysical reflexion and speculation. In this context, Angehrn (1996:305), in view of the interdependence of mythological and historical thinking, recognises a reshaping of historical thinking through assumptions based on a teleologically oriented philosophy of history, which he labels as a prototype of a fatalistic interpretation of the world.

Basically his statement emphasizes a process that began in medieval times and has expanded since mid 18th century, in the course of which divine predestination is replaced by a concept of development that runs through the course of history.

In this context, the aim of cultural evolution still preserves the perception that development leads from a starting point to a better goal (Ickerodt 2004a:42f. s.a. Ickerodt 2005b; 2006. ${ }^{12}$. In this way Angehrn expounds the problems of a sub-

\footnotetext{
10 "Mission to Mars" (USA 2000).

${ }^{11}$ For a systematic classification of human concepts of time, see Ickerodt (2004a).

${ }^{12}$ This notion did not remain unchallenged. As an example, J. G. Herder refers in his "Auch eine Philosophie der Geschichte zur Bildung der Menschheit" (1774) to this topic and criticizes expedient progress and cumulating enlightenment as principles of history.
} 
liminal continuation of former transcendentally oriented teleological thinking, which in early modern history and in modernity were seemingly abandoned in favour of the benefit of a scientifically based teleonoumus concept. On a metalevel, teleological concepts of history are still valid ${ }^{13}$.

Finally, the teleological fundamentals of the European conception of history in the 18th century, developed for example by Johann Gottfried Herder (1744-1803), or in the 19th century for example by the social Darwinist Herbert Spencer (1820-1903) or the evolutionists Lewis Henry Morgan (1818-1881) and Sir Edward Burnett Tylor (1832-1917), are still extremely valid, although they may currently appear in different shapes or forms. At the core of such a meta-narration based on teleology are concepts of society and values referring to an unilinear form of evolution which may be characterized in terms of progress thinking, secularization and rationalism as well as individualism and political self-determination. Indeed, these values have to be seen in combination with, and/or complementary to, chauvinism, which sought for self-legitimation within teleological concepts of history and which have been slowly abandoned only in recent years (racism, political emancipation, decolonization etc.).

This process of changing social values has to be seen as part of a massive and permanent process of social and economic restructuring and reorientation. At the beginning of the 19 th century, about $75 \%$ of the working population were employed in agriculture, and today it is not even as much as $5 \%$. The rapidly expanding service and information sectors, with their specific needs, have long ago superseded industry as source of livelihood in urban and globalised post-war postmodern society. As a result of this process, traditional, transcendentally legitimated values are beginning to be lost. They are compensated by values that draw their legitimation from scientific arguments. Here, it is crucial to understand that this change in values takes place on an visible level, while the metaphysical level remains unconsidered.

An important conceptional and integratively operating precondition of this economic and social process of reorientation is chronological thinking, which has been emerging since the Middle Ages. It is based on a growing public acceptance of the concept of linear-progressive time and a better understanding of interaction chains as a predominant form of time perception (Ickerodt 2004a:76-84). This concept of linear-progressive time should and may help a highly mobile society to synchronize social and economic behaviour. For this, society needs to develop appropriate structures, such as the big narrative, which is propagated by means of pictures and metaphors.

\subsection{Development pathways - the past is the key to the future}

If a visitor walks along a time path, as in Raddusch, Mettmann or Hanover, he will, apart from other possible interpretations and based on socially anchored apriori assumptions, comprehend his own social and technological progress: He himself constitutes the momentary endpoint of his own cultural and historical development and represents the dominant present on the development pathway.

\footnotetext{
${ }^{13}$ The most important theoretical influences are the 2nd Law of Thermodynamics and the theory of evolution, while the inherent consequences of the philosophy of history never found a broad reception within the humanities (Ickerodt 2004a; 2004b; 2005b; 2006.).
} 
This interpretation is learned throughout one's own life-history and is connected to social grouping dependencies and to one's own experiences (Ickerodt 2004a). It is used in different forms and modes for social self-assurance and provides social identity.

The best example is the original site at the Neanderthal Museum at Mettmann and the "space-time axis" (Raum-Zeit-Achse) development path, which provides the visitor with an understanding of chronology. The end of the pathway is marked by a plate with the sentence: "Today, you look back" (Heute schauen Sie zurück). While looking back from this endpoint one can read a list of historical events: 2000 human genes are sequenced, 1989 first mobile phone, 1969 first moon landing, 1946 first computer, 1938 first nuclear fission, 1924 first television, 1901 first motor-driven flight, 1886 first automobile, 1859 Darwin's theory of evolution, 1856 Fuhlrott discovers the remains of Neanderthal man, 1830 invention of the steam engine, 1510 Copernicus put the sun in the middle of the planetary system, 1450 Gutenberg invents printing, 1119 foundation of the University of Bologna, 800 coronation of Charlemagne, 410 the sacking of Rome by Western Goths, 0 the beginning of the calculation of time ${ }^{14}$.

Stress is laid on scientific/technological innovations suggesting goal-oriented evolution to the present position today. Alternatively, some other events in the cultural evolution of mankind might have been chosen, such as the following which have been selected at random, to create a totally different picture of man's cultural evolution, e.g. the Battle of Lechfeld (955), Rousseau's „Du contrat social" (1762), the assault of the Bastille (1789), the Code Civil (1804), the Hambacher feast (1832), the suppression of the Herero uprising (1904), the United Nations Charter (1945), the Tschernobyl disaster (1986) and the European Convention for Protection of National Minorities (1995).

Thereby it has to be taken into consideration that the developer of such a didactical concept has to struggle with a small framework of understanding. He has to fulfil the expectations of the public and to provide a certain sensation of novelty. In the example of the Neanderthal Museum at Mettman, the narrative of accelerating social and technological progress had been chosen. This narrative should provide for the visitor, against the background of the past, a critical or non-critical examination of (1) his origin based on linear-progressive continuity thinking, and of (2) social and cultural change.

A variation of this topic path of evolution can be found at the ErlebnisZoo Hannover. In contrast to the authentic sites of Mettmann and Raddusch, the Hannover Zoo is a scientifically inspired archaeological/historical (i.e. 2b) setting. The way it is understood, as in the case of Mettmann and Raddusch, is clearly defined since the pathway of evolution may be entered at either end.

\footnotetext{
${ }^{14}$ This same orientation can be seen for the Pleistocene pathway sector: "13,000 years ago first ceramics, 15,000 years ago first arrow heads, 20,000 years ago first needle with eye, 33,000 years ago first cave paintings, 35,000 years ago first appearance of Homo sapiens sapiens in Europe, 40,000 years ago first adornment and 200,000 years ago first appearance of Homo sapiens neanderthalensis in Europe".
} 


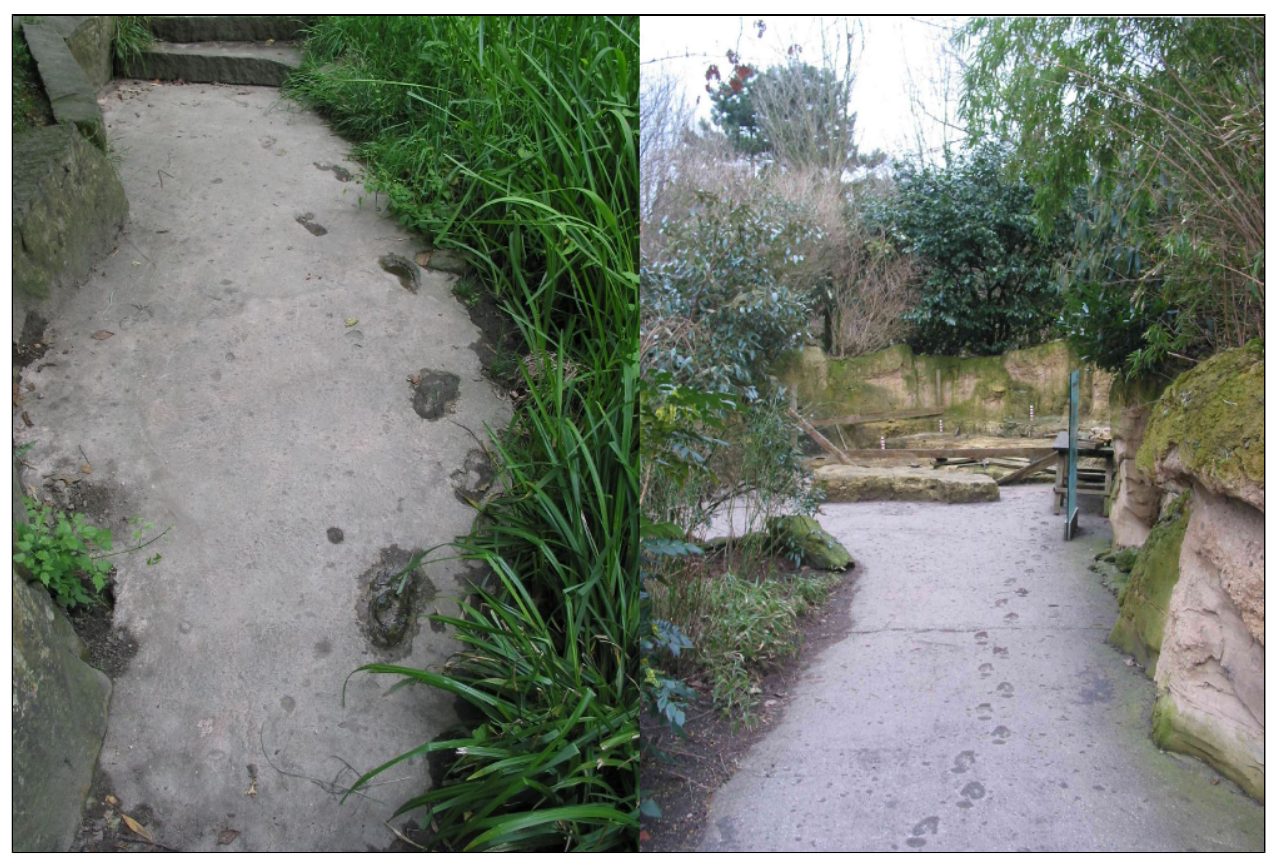

Figure 13. At the Erlebniszoo Hannover the visitor can gain an understanding of the biological and cultural evolution of man represented by a pathway on which one can see (left) imitations of the Laetoli footprints, changing uphill to (right) a track of shoe prints leading to a fake excavation (photo by the author).

The uphill trail leads the visitor to the excavation mentioned above. It symbolizes both technological/scientific progress and our preoccupation with our own origins and is a common topic in numerous fictional books and movies. Near the excavation, downhill, one can find the Laetoli footprints (Fig. 3b), explained on an information board. After a short way uphill in the direction of the excavation the footprints turn into a track with shoeprints (Fig. 3a) as well as into the prints of a primate. While the first track leads ahead, the second seems to run (off the main path).

Similarly, in this case scientific/technological progress based on linear-progressive continuity thinking is the major topic. The uphill track is used as a metaphor for unilinear evolution and in this case is combined with the motif of devolution or cultural regression, symbolized by the primate track leading off the main path (Ickerodt 2004a:125-128). Use of this combination of motifs is not only a result of (materialistic) enthusiasm for progress, but also expresses the fear of being a loser in a competitive society.

\section{$5 \quad$ Concluding remarks}

It is now almost three decades since archaeological research and its administrative arm, cultural heritage management, began to be aware of the social effects of their work. Towards the end of the 1980s, one became increasingly concerned with the political misuse of archaeology in the Third Reich. This issue made both academic and administrative archaeological circles conscious of the problem of reactivity. In sociology one uses this term to describe the interdependence of so- 
ciety and science. This in fact opened up a new field of research for archaeology (Ickerodt 2004a, 2004b).

This step in the direction of a discipline dealing with the sociology of science not only opens up completely new perspectives for archaeological interpretation, since it permits a distinction to be made between social and scientific interpretation patterns or modes. It also represents the first step in a new form of inquiry about the content of our own discipline, which also of course bears on the influence of archaeological research work on the contemporary social environment. In this sense, contemplation of the social dimension of archaeology permits a completely new view of the evolution of archaeology itself: It questions the quality of archaeological interpretation and interpretation patterns and, on the other hand, the feedback relationship between society and the archaeological world.

This new perspective enables the scientific world to distinguish between social and scientific patterns of interpretation and modes of understanding. With it, archaeological research gets a second tool apart from natural science to assure the quality of its own work. It is based on investigating the structural determinism of scientific recognition and interpretation in their historic dimension and in their feedback to both scientific and social environments.

This preoccupation with problems in the field of research history or the history of mentalities confronts the archaeological world with completely new questions. In which ways does archaeological research influence the imparting of social values? How can this process of imparting social values be scientifically validated in a responsible manner?

These are the above mentioned questions dealing with the field of ethics of science that have to be taken into consideration when investigating the social influence of archaeology. To be aware of the dimensions of this research field, as a first step this paper examines the historically evolving reference system "archaeology" as a component of our social identity that has to be outlined.

Therefore, the first section "Founding myth and historical thinking" examined the anthropological basis of our occupation with our own origins. In this context, the close relationship of scientific thinking and metaphysics was emphasized as the cause for the indistinct boundary between these two and for holding a teleologic conception of history. This teleologic concept of history is the big narrative which forms a framework for our perception of the biological and historical evolution of man.

It should not be forgotten that our commitment to know about our origins has an identity constituent and therefore a stabilizing effect on society. This effect results from the fact that dealing with the past has an interpretative and a legitimating functionality, which must explain provenance on one hand and change on the other. It is part of man's ability to adapt. Ickerodt (2004a) illustrated this phenomenon with reference to the image of prehistoric man. On an intrasocial level, it is an appropriate symbol to promote linear-progressive continuity thinking in terms of origins of things and, on the other hand, the image of prehistoric man is a very useful rationale to steer the process of social differentiation on an intrasocial and extrasocial level.

In the next step the research target was defined, i.e. examination of the way archaeological/historical sites in open-air museums, leisure parks and motion pictures are embedded in our understanding of history. As part of the research 
strategy, the sites where history is imparted were divided into the two categories, authentic and fictitious sites.

In both cases, "time path" through time were used to "anchor" the sites in history. The layman who is less interested in history can walk along such a time path, thus experiencing the chronological succession beneath his feet. How this works can be understood with the help of the cultural history table in Section 4. We have chosen three examples. Firstly there are the so-called "time plank" of Raddusch and a "time-space axis" near the site in Mettman where the Neandertal remains were found - both represent an authentic historical or heritage landscape. Secondly, in Hanover ErlebnisZoo, an evolution trail incorporating a fictive historical landscape, which shows that archaeological information can be presented to the public independently of the authenticity of an archaeological site or find.

As far as the content of these two examples is concerned, it is clear that they are based on the idea of scientific/technological progress. This idea was developed in its current form in the 19th century as a general metanarration.

This interpretation can be further clarified via the iconographic relationship of the evolution trail or simply by a footprint. In the social perspective, a footprint stands for one's own existence and metaphorically it stands for a goal that has not yet been attained. Over and above this, a footprint is a symbol for the scientific process of evaluation or investigation.

This leads back to the question of how society digests archaeological data, and what significance this process has. It promotes the creation of social identity and it helps to structure and canalize social behaviour. On the basis of the examples shown above, it is possible to depict a scale of values which originates from the typical European mode of thinking in terms of progress. On a metaphysical level, we can see that, in the process of secularisation, traditional concepts and the values and norms based on them are simply "dressed up" into new iconographic pictures. And it must be taken into consideration that, with respect to their metaphysical incorporation, they are a product of a process of adaptation to time. ${ }^{15}$ In the sense of Western positivism, these concepts receive their justification and are legitimized by way of general scientific research. Nevertheless it would be incorrect to trace them back to a specific type of understanding, since the possible types of understanding and the resulting capacity to affect the prepared pictures depends on the social environment as well as on one's own perception and utilization.

This condition turns out to be highly problematic for imparting archaeological knowledge, since it doesn't only have an identity-creating effect but also tends to mould mentality. In this spirit I wish to end this paper, which dealt with the social implications of archaeological research, with another quotation from Hobsbawm. On one side it shows that the archaeological community must be both self-reflective and self-critical. On the other hand it clarifies the need for universally implemented archaeological didactics: "So far I have held the opinion that the historian's job, unlike that of a nuclear physicist, cannot do anyone any harm. However, I now know better. Just as the workshops in which the IRA turned fer-

\footnotetext{
${ }^{15}$ Ickerodt (2006) has developed a kybernetic model to enable this process to be better understood as a standard cycle in an evolutionary process.
} 
tilizer into high explosive, the places where we work can be converted into bomb factories"16. (Hobsbawm 1994).

\section{References}

Ahrens, C. 1976: Vorgeschichtliche Wanderziele im Harburger Raum. Veröffentlichung des Helms-Museums 31. Hamburg 1976.

Alsdorf, D. 1980: Hügelgräber, Burgen, Kreuzsteine. Bildführer zu vorgeschichtlichen und mittelalterlichen Denkmälern im Raum Stade. Stade 1980.

Angehrn, E. 1996: Ursprungsmythos und Geschichtsdenken. In: H. Nagl-Docekal (Hrsg.), Der Sinn des Historischen. Geschichtsphilosophische Debatten (= P. Nanz [Hrsg.], Philosophie der Gegenwart). Frankfurt am Main 1996, 305-332.

Bärenfänger, R. (Hrsg.) 1999: Führer zu archäologischen Denkmälern in Deutschland 35. Ostfriesland. Stuttgart 1999.

Bichl, A., Griebl, M., La Speranza, M., Reisinger, B. 2003: Carnutum, Vindobona, Bernsteinstraße. Wien 2003.

Bock, H. Fritsch, B., Mittag, L. 2006: Großsteingräber in der Altmark. Halle (Saale) 2006.

Böhme, H. 1989: Die Ästhetik der Ruinen. In: Kamper, D. und Wulf, C., Der Schein des Schönen. Göttingen 1989, 287-304.

Burl, A. 1995: A guide to the stone circles of Britain, Ireland and Brittany. New Haven, London 1995.

Führer zu vor- und frühgeschichtlichen Denkmälern 1976a: Führer zu vor- und frühgeschichtlichen Denkmälern. Das Elb-Weser-Dreieck I. Einführende Aufsätze. Herausgegeben vom Römisch-Germanischen Zentralmuseum Mainz in Verbindung mit dem Nordwestdeutschen und dem West- und Süddeutschen Verband für Altertumsforschung. Mainz 1976.

Führer zu vor- und frühgeschichtlichen Denkmälern 1976b: Führer zu vor- und frühgeschichtlichen Denkmälern 30. Das Elb-Weser-Dreieck II. Forschungsprobleme - Exkursionen Stade, Bremervörde, Zeven, Buxtehude. Herausgegeben vom RömischGermanischen Zentralmuseum Mainz in Verbindung mit dem Nordwestdeutschen und dem West- und Süddeutschen Verband für Altertumsforschung. Mainz 1976.

Führer zu vor- und frühgeschichtlichen Denkmälern 1976c: Führer zu vor- und frühgeschichtlichen Denkmälern 31. Das Elb-Weser-Dreieck III. Exkursionen Bremerhaven, Cuxhaven, Worpswede. Herausgegeben vom Römisch-Germanischen Zentralmuseum Mainz in Verbindung mit dem Nordwestdeutschen und dem West- und Süddeutschen Verband für Altertumsforschung. Mainz 1976.

Gottwald, J. R. 1991a: Sehenswerte Großsteingräber im Nordsee- und Ostseeraum: Jütland/ Dänemark, Norddeutschland, östliche Niederlande. Ein Bilderbuchwegweiser in jungsteinzeitliche Vergangenheit vor 4000-5000 Jahren, Teil 1, 1-336 Seiten. Troppau Gerasdorf bei Wien 1991.

Gottwald J. R. 1991b: Sehenswerte Großsteingräber im Nordsee- und Ostseeraum: Jütland/ Dänemark, Norddeutschland, östliche Niederlande. Ein Bilderbuchwegweiser in jungsteinzeitliche Vergangenheit vor 4000-5000 Jahren, Teil 2, Seiten 337-672. Troppau Gerasdorf bei Wien 1991.

Habermas, J. 1976: Geschichte und Evolution. In: J. Habermas, Zur Rekonstruktion des Historischen Materialismus. Frankfurt/M. 51990, 200-259.

\footnotetext{
${ }^{16}$ Original in German, translation by the author.
} 
Hesse, S. 2003: Theiss Archäologieführer. Niedersachsen. Stuttgart 2003.

Hobsbawm, E. 1994: Die Erfindung der Vergangenheit. Die Zeit 37, 1994, 49.

Ickerodt, U. 2004a: Bilder von Archäologen, Bilder von Urmenschen. Ein kultur- und mentalitätsgeschichtlicher Beitrag zur Genese der prähistorischen Archäologie am Beispiel zeitgenössischer Quellen. Dissertation zur Erlangung des Grades eines Doktors der Philosophie des Fachbereichs der Kunst-, Orient- und Altertumswissenschaften der Martin-Luther-Universität Halle-Wittenberg (Bonn 2004) (http:// sundoc.bibliothek.uni-halle.de/diss-online/05/06H070/ index.htm).

Ickerodt, U. 2004b: Die Legitimierung des Status quo: Ein Beitrag zur gesellschaftlichen und politischen Relevanz prähistorischen Forschens. Rundbrief der Arbeitsgemeinschaft Theorie in der Archäologie 3(1-2), 2004, 10-23.

Ickerodt, U. 2005a: Hobsbawms erfundene Traditionen - Archäologie als Soziales Phänomen. Archäologisches Nachrichtenblatt 10(2), 2005, 167-174.

Ickerodt, U. 2005b: Ickerodt, Das Erbe der Urmenschen - Eine Anmerkung zur gesellschaftlichen Relevanz der prähistorischen Forschung. Rundbrief der Arbeitsgemeinschaft Theorie in der Archäologie 4 (1), 2005, 14-23.

Ickerodt, U. 2006: Das Erbe der Urmenschen - eine Erwiderung auf Porrs Kritik. Rundbrief der Arbeitsgemeinschaft Theorie in der Archäologie 5 (2), 2006, 9-19.

Ickerodt, U. 2007: Die räumliche Dimension der Geschichte: Kulturlandschaft als Ort der historischen Wissensvermittlung. In: A. Bauerochse, H. Haßmann \& U. Ickerodt (Hrsg.), Kulturlandschaft. administrativ - digital - touristisch. Initiativen zum Umweltschutz 67 (Berlin 2007) 255-277.

Lauer, H. A. (1979): Archäologische Wanderungen I. Ost Niedersachsen. Ein Führer zu Sehenswürdigkeiten der Ur- und Frühgeschichte. Göttingen 1979.

Lauer, H. A. (1983): Archäologische Wanderungen II. Nördliches Niedersachsen, westliche Lüneburger Heide, Mittelwesergebiet. Ein Führer zu Sehenswürdigkeiten der Ur- und Frühgeschichte. Angerstein 1983.

Lauer, H. A. (1988): Archäologische Wanderungen III. Südniedersachsen. Ein Führer zu Sehenswürdigkeiten der Ur- und Frühgeschichte. Angerstein 1988.

Mosig, D. W. 1997: H. P. Lovecraft: Mythenschöpfer. In: F. Rottensteiner, H. P. Lovecrafts kosmisches Grauen. (= Phantastische Bibliothek 344) Frankfurt am Main 1997, 162173.

Schön, M. 1995: Wege in die Vorgeschichte 1. Vorgeschichtspfade bei Sievern und Flögeln im Landkreis Cuxhaven. Bad Bederkesa 1995.

Sielmann, B. 1975: Archäologischer Wanderpfad Fischbeker Heide. Veröffentlichung des Helms-Museums 25. Hamburgisches Museum für Vor- und Frühgeschichte. Hamburg 1975.

White, H. 1973: Metahistory. Die historische Einbildungskraft im 19. Jahrhundert in Europa Stuttgart 1994.

White, H. 1996: Literaturtheorie und Geschichtsschreibung. In: H. Nagl-Docekal (Hrsg.), Der Sinn des Historischen. Geschichtsphilosophische Debatten (= P. Nanz (Hrsg.), Philosophie der Gegenwart). Frankfurt am Main 1996, 67-106.

Zeitspuren 1998: Ausstellungsführer Museum Hösseringen. Zeitspuren. Wege zu archäologischen Denkmälern der Region Uelzen. Steinreiche Heide. Verwendung und Bearbeitung von Findlingen in der Lüneburger Heide. (Hösseringen) 1998. 


\section{Appendix 1}

Table 1. Archaeological sites, open-air museums, leisure parks and motion pictures as places where an understanding of history is imparted.

\begin{tabular}{|c|c|c|c|c|c|}
\hline & Quality & \multicolumn{2}{|c|}{ 1. authentic } & \multicolumn{2}{|c|}{ 2. fictitious } \\
\hline & Locality and object & $\begin{array}{l}\text { a. original } \\
\text { site in situ }\end{array}$ & $\begin{array}{c}\mathrm{b} . \\
\text { reconstructed }\end{array}$ & $\begin{array}{l}\text { a. } \\
\text { scientifically } \\
\text { proven }\end{array}$ & $\begin{array}{c}\text { b. } \\
\text { scientifically } \\
\text { inspired }\end{array}$ \\
\hline & \multicolumn{5}{|l|}{ SCHLESWIG-HOLSTEIN } \\
\hline 1 & $\begin{array}{l}\text { Archäologisch- } \\
\text { Ökologisches Zentrum } \\
\text { (AÖZA) } \\
\text { Albersdorf, } \\
\text { Schleswig-Holstein }\end{array}$ & $\begin{array}{l}\text { archaeological } \\
\text { site made } \\
\text { accessible }\end{array}$ & $\begin{array}{l}\text { Neolithic } \\
\text { settlement and } \\
\text { crops }\end{array}$ & & \\
\hline 2 & $\begin{array}{l}\text { Oldenburger } \\
\text { Wallmuseum } \\
\text { Oldenburg (Holstein), } \\
\text { Schleswig-Holstein }\end{array}$ & & $\begin{array}{l}\text { Partly } \\
\text { reconstructed } \\
\text { Slav } \\
\text { settlement }\end{array}$ & & \\
\hline 3 & $\begin{array}{l}\text { Danewerk and } \\
\text { Waldemarsmauer } \\
\text { Schleswig, } \\
\text { Schleswig-Holstein }\end{array}$ & $\begin{array}{l}\text { archaeological } \\
\text { sites made } \\
\text { accessible }\end{array}$ & & & \\
\hline 4 & $\begin{array}{l}\text { Haithabu } \\
\text { Schleswig, } \\
\text { Schleswig-Holstein }\end{array}$ & & $\begin{array}{l}\text { Viking age } \\
\text { buildings with } \\
\text { a protected } \\
\text { landscape area }\end{array}$ & & \\
\hline 5 & $\begin{array}{l}\text { Archaeological hiking } \\
\text { trail Ochsenweg } \\
\text { Schleswig, } \\
\text { Schleswig-Holstein }\end{array}$ & $\begin{array}{l}\text { archaeological } \\
\text { sites made } \\
\text { accessible }\end{array}$ & & & \\
\hline & \multicolumn{5}{|c|}{ MECKLENBURG-HITHER-POMMERANIA } \\
\hline 6 & $\begin{array}{l}\text { Archäologisches } \\
\text { Freilichtmuseum Groß } \\
\text { Raden } \\
\text { Groß Raden, } \\
\text { Mecklenburg- } \\
\text { Vorpommern }\end{array}$ & & $\begin{array}{l}\text { Slav } \\
\text { settlement and } \\
\text { sanctuary }\end{array}$ & & \\
\hline 7 & $\begin{array}{l}\text { Steinzeitdorf Kussow } \\
\text { Kussow, } \\
\text { Mecklenburg- } \\
\text { Vorpommern }\end{array}$ & & $\begin{array}{l}\text { Neolithic } \\
\text { settlement and } \\
\text { crops }\end{array}$ & & \\
\hline 8 & $\begin{array}{l}\text { Freilichtmuseum } \\
\text { „Ukranenland“ } \\
\text { Torgelow, } \\
\text { Mecklenburg- } \\
\text { Vorpommern }\end{array}$ & & $\begin{array}{l}\text { Slav } \\
\text { settlement and } \\
\text { sanctuary }\end{array}$ & & \\
\hline & \multicolumn{5}{|l|}{ LOWER SAXONY } \\
\hline 9 & $\begin{array}{l}\text { Museumsdorf } \\
\text { Cloppenburg } \\
\text { Cloppenburg, } \\
\text { Niedersachsen }\end{array}$ & & $\begin{array}{l}\text { historic } \\
\text { buildings } \\
\text { gathered } \\
\text { together from } \\
\text { different areas }\end{array}$ & & \\
\hline
\end{tabular}




\begin{tabular}{|c|c|c|c|c|c|}
\hline & \multirow{2}{*}{$\begin{array}{c}\text { Quality } \\
\text { Locality and object }\end{array}$} & \multicolumn{2}{|c|}{ 1. authentic } & \multicolumn{2}{|c|}{ 2. fictitious } \\
\hline & & $\begin{array}{l}\text { a. original } \\
\text { site in situ }\end{array}$ & $\begin{array}{c}\mathrm{b} . \\
\text { reconstructed }\end{array}$ & $\begin{array}{c}\text { a. } \\
\text { scientifically } \\
\text { proven }\end{array}$ & $\begin{array}{c}\text { b. } \\
\text { scientifically } \\
\text { inspired }\end{array}$ \\
\hline 10 & $\begin{array}{l}\text { Vorgeschichtspfad } \\
\text { Flögeln } \\
\text { Flögeln, } \\
\text { Niedersachsen }\end{array}$ & $\begin{array}{l}\text { archaeological } \\
\text { sites made } \\
\text { accessible }\end{array}$ & & & \\
\hline 11 & $\begin{array}{l}\text { neolithic grave } \\
\text { Gudendorf, } \\
\text { Niedersachsen }\end{array}$ & $\begin{array}{l}\text { archaeological } \\
\text { site made } \\
\text { accessible }\end{array}$ & & & \\
\hline 12 & $\begin{array}{l}\text { Erlebniszoo } \\
\text { Hannover, } \\
\text { Niedersachsen }\end{array}$ & & & $\begin{array}{l}\text { Pathway of } \\
\text { Evolution } \\
\text { with Laetoli } \\
\text { footprints, an } \\
\text { archaeological } \\
\text { excavation, } \\
\text { a prehistoric } \\
\text { dwelling and } \\
\text { a Neanderthal } \\
\text { burial }\end{array}$ & \\
\hline 13 & $\begin{array}{l}\text { Archäologisches } \\
\text { Zentrum Hitzacker } \\
\text { Hitzacker, } \\
\text { Niedersachsen }\end{array}$ & & $\begin{array}{l}\text { Bronze Age } \\
\text { settlement }\end{array}$ & & \\
\hline 14 & $\begin{array}{l}\text { Museum und Park } \\
\text { Kalkriese } \\
\text { Kalkriese, } \\
\text { Niedersachsen }\end{array}$ & $\begin{array}{l}\text { archaeological } \\
\text { site made } \\
\text { accessible }\end{array}$ & & & \\
\hline 15 & $\begin{array}{l}\text { Dino Park } \\
\text { Münchehagen, } \\
\text { Niedersachsen }\end{array}$ & $\begin{array}{l}\text { fossil Dinosaur } \\
\text { tracks made } \\
\text { accessible }\end{array}$ & $\begin{array}{l}\text { Dinosaurs and } \\
\text { prehistoric } \\
\text { mammals } \\
\text { (partly within } \\
\text { their historic } \\
\text { environment) }\end{array}$ & $\begin{array}{l}\text { Prehistoric } \\
\text { dwelling }\end{array}$ & \\
\hline 16 & $\begin{array}{l}\text { Natureum } \\
\text { Neuhaus, } \\
\text { Niedersachsen }\end{array}$ & & Dinosaurs & $\begin{array}{l}\text { two areas with } \\
\text { prehistoric } \\
\text { dwellings }\end{array}$ & \\
\hline 17 & $\begin{array}{l}\text { bronzezeitliches Haus } \\
\text { Hahnenkooper-Mühle } \\
\text { Rodenkirchen, } \\
\text { Niedersachsen }\end{array}$ & & $\begin{array}{l}\text { Bronze Age } \\
\text { dwelling }\end{array}$ & & \\
\hline 18 & $\begin{array}{l}\text { Vorgeschichtspfad } \\
\text { Sievern } \\
\text { Sievern, } \\
\text { Niedersachsen }\end{array}$ & $\begin{array}{l}\text { archaeological } \\
\text { site made } \\
\text { accessible }\end{array}$ & & & \\
\hline 19 & $\begin{array}{l}\text { Erse-Park } \\
\text { Uetze, } \\
\text { Niedersachsen }\end{array}$ & & $\begin{array}{l}\text { Dinosaurs and } \\
\text { prehistoric } \\
\text { mammals } \\
\text { (partly within } \\
\text { their historic } \\
\text { environment) }\end{array}$ & $\begin{array}{l}\text { Prehistoric } \\
\text { people, tents }\end{array}$ & \\
\hline 20 & $\begin{array}{l}\text { Torf- und } \\
\text { Siedlungsmuseum } \\
\text { Wiesmoor, } \\
\text { Niedersachsen }\end{array}$ & & & $\begin{array}{l}\text { Settlement } \\
\text { of peatland } \\
\text { colonists }\end{array}$ & \\
\hline
\end{tabular}




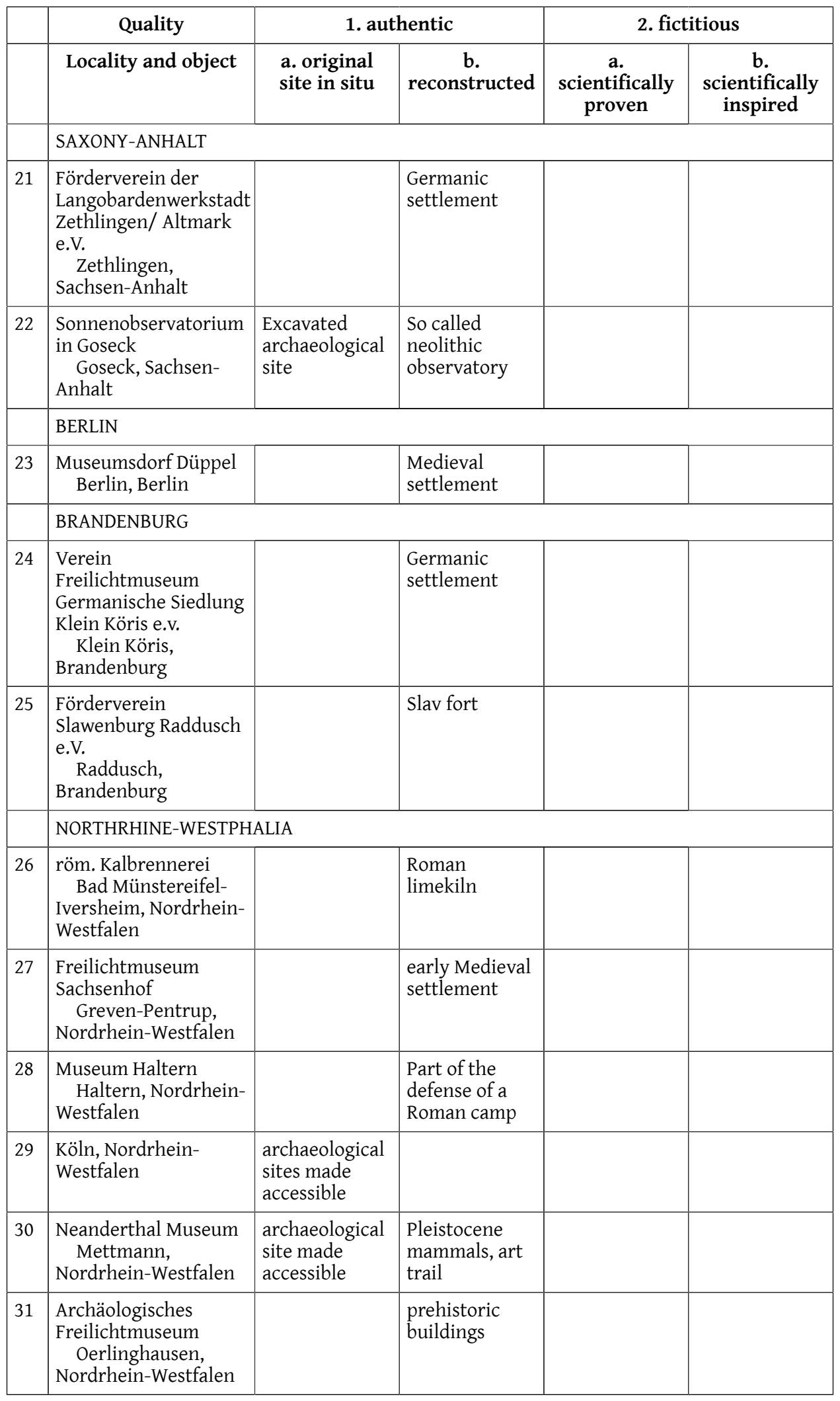




\begin{tabular}{|c|c|c|c|c|c|}
\hline & Quality & \multicolumn{2}{|c|}{ 1. authentic } & \multicolumn{2}{|c|}{ 2. fictitious } \\
\hline & Locality and object & $\begin{array}{l}\text { a. original } \\
\text { site in situ }\end{array}$ & $\begin{array}{c}\mathrm{b} . \\
\text { reconstructed }\end{array}$ & $\begin{array}{c}\text { a. } \\
\text { scientifically } \\
\text { proven }\end{array}$ & $\begin{array}{c}\text { b. } \\
\text { scientifically } \\
\text { inspired }\end{array}$ \\
\hline \multirow[t]{2}{*}{32} & $\begin{array}{l}\text { Archäologischer Park/ } \\
\text { Regionalmuseum } \\
\text { Xanten } \\
\text { Xanten, Nordrhein- } \\
\text { Westfalen }\end{array}$ & $\begin{array}{l}\text { archaeological } \\
\text { site made } \\
\text { accessible }\end{array}$ & $\begin{array}{l}\text { Roman } \\
\text { settlement }\end{array}$ & & \\
\hline & \multicolumn{5}{|l|}{ RHINELAND-PALATINATE } \\
\hline 33 & $\begin{array}{l}\text { Limeswachturm } \\
\text { Bad Ems, } \\
\text { Rheinland-Pfalz }\end{array}$ & & $\begin{array}{l}\text { Roman } \\
\text { watchtower on } \\
\text { the Limes }\end{array}$ & & \\
\hline 34 & $\begin{array}{l}\text { römische Villa } \\
\text { Bad Neuenahr- } \\
\text { Ahrweiler, Rheinland- } \\
\text { Pfalz }\end{array}$ & $\begin{array}{l}\text { archaeological } \\
\text { site made } \\
\text { accessible }\end{array}$ & & & \\
\hline 35 & $\begin{array}{l}\text { Europäischer } \\
\text { Kulturpark } \\
\text { Bliesbrück-Rheinheim } \\
\text { Bliesbrück- } \\
\text { Rheinheim, } \\
\text { Rheinland-Pfalz } \\
\text { (Deutschland)/ } \\
\text { Frankreich, }\end{array}$ & $\begin{array}{l}\text { archaeological } \\
\text { sites made } \\
\text { accessible }\end{array}$ & & & \\
\hline 36 & $\begin{array}{l}\text { Römische Villa Borg } \\
\text { Borg, Rheinland- } \\
\text { Pfalz }\end{array}$ & & $\begin{array}{l}\text { Roman villa } \\
\text { rustica }\end{array}$ & & \\
\hline 37 & $\begin{array}{l}\text { Freilichtmuseum } \\
\text { Bundenbach } \\
\text { Bundenbach, } \\
\text { Rheinland-Pfalz }\end{array}$ & & $\begin{array}{l}\text { Celtic } \\
\text { settlement }\end{array}$ & & \\
\hline 38 & $\begin{array}{l}\text { Römermuseum } \\
\text { Homburg- } \\
\text { Schwarzenacker } \\
\text { Homburg- } \\
\text { Schwarzenacker, } \\
\text { Rheinland-Pfalz, }\end{array}$ & $\begin{array}{l}\text { archaeological } \\
\text { site made } \\
\text { accessible }\end{array}$ & $\begin{array}{l}\text { Roman } \\
\text { settlement }\end{array}$ & & \\
\hline 39 & $\begin{array}{l}\text { Kaiserpfalz Ingelheim } \\
\text { Besucherzentrum } \\
\text { Ingelheim, } \\
\text { Rheinland-Pfalz }\end{array}$ & $\begin{array}{l}\text { archaeological } \\
\text { site made } \\
\text { accessible }\end{array}$ & & & \\
\hline 40 & $\begin{array}{l}\text { Mainz, Rheinland- } \\
\text { Pfalz }\end{array}$ & $\begin{array}{l}\text { archaeological } \\
\text { sites made } \\
\text { accessible }\end{array}$ & & & \\
\hline 41 & $\begin{array}{l}\text { Martberg (Mons } \\
\text { Martis) } \\
\text { Martberg, } \\
\text { Rheinland-Pfalz }\end{array}$ & & $\begin{array}{l}\text { Celto-Roman } \\
\text { refuge }\end{array}$ & & \\
\hline 42 & $\begin{array}{l}\text { Keltendorf Steinbach } \\
\text { Steinbach, } \\
\text { Rheinland-Pfalz }\end{array}$ & & $\begin{array}{l}\text { Celtic } \\
\text { settlement }\end{array}$ & & \\
\hline
\end{tabular}




\begin{tabular}{|c|c|c|c|c|c|}
\hline & Quality & \multicolumn{2}{|c|}{ 1. authentic } & \multicolumn{2}{|c|}{ 2. fictitious } \\
\hline & Locality and object & $\begin{array}{l}\text { a. original } \\
\text { site in situ }\end{array}$ & $\begin{array}{c}\mathrm{b} . \\
\text { reconstructed }\end{array}$ & $\begin{array}{c}\text { a. } \\
\text { scientifically } \\
\text { proven }\end{array}$ & $\begin{array}{c}\text { b. } \\
\text { scientifically } \\
\text { inspired }\end{array}$ \\
\hline 43 & $\begin{array}{l}\text { Gallo-römischer } \\
\text { Tempelbezirk Tawern } \\
\text { Tawern, Rheinland- } \\
\text { Pfalz }\end{array}$ & & $\begin{array}{l}\text { Celto-Roman } \\
\text { refuge }\end{array}$ & & \\
\hline \multirow[t]{2}{*}{44} & Trier, Rheinland-Pfalz & $\begin{array}{l}\text { arch. site made } \\
\text { accessible }\end{array}$ & & & \\
\hline & HESSE & & & & \\
\hline 45 & $\begin{array}{l}\text { Glauburg-Museum } \\
\text { Glauburg, Hessen }\end{array}$ & $\begin{array}{l}\text { arch. site made } \\
\text { accessible }\end{array}$ & & & \\
\hline 46 & $\begin{array}{l}\text { Römerkastell Saalburg } \\
\text { Bad Homburg, } \\
\text { Hessen }\end{array}$ & $\begin{array}{l}\text { arch. site made } \\
\text { accessible }\end{array}$ & Roman castle & & \\
\hline \multirow[t]{2}{*}{47} & $\begin{array}{l}\text { Reilichtmuseum } \\
\text { Römische villa } \\
\text { Haselburg } \\
\text { Höchst, Hessen }\end{array}$ & & $\begin{array}{l}\text { Roman villa } \\
\text { rustica }\end{array}$ & & \\
\hline & \multicolumn{5}{|l|}{ THURINGIA } \\
\hline 48 & $\begin{array}{l}\text { Versuchsgelände } \\
\text { zur experimentellen } \\
\text { Archäologie } \\
\text { Haarhausen, } \\
\text { Thüringen }\end{array}$ & & $\begin{array}{l}\text { Roman } \\
\text { potter's kiln, } \\
\text { Germanic } \\
\text { dwellings }\end{array}$ & & \\
\hline 49 & $\begin{array}{l}\text { Opfermoor Vogtei } \\
\text { Niederdorla, } \\
\text { Thüringen }\end{array}$ & & $\begin{array}{l}\text { Germanic } \\
\text { refuge and } \\
\text { settlement }\end{array}$ & & \\
\hline 50 & $\begin{array}{l}\text { Freilichtmuseum } \\
\text { Königspfalz Tilleda } \\
\text { Tilleda, Thüringen }\end{array}$ & & $\begin{array}{l}\text { medieval } \\
\text { settlement }\end{array}$ & & \\
\hline \multirow[t]{2}{*}{51} & $\begin{array}{l}\text { Freilichtanlage } \\
\text { Funkenburg } \\
\text { Westgreußen, } \\
\text { Thüringen }\end{array}$ & & $\begin{array}{l}\text { Germanic } \\
\text { castle }\end{array}$ & & \\
\hline & \multicolumn{5}{|l|}{ SAXONY } \\
\hline 52 & $\begin{array}{l}\text { Mittelalterliche } \\
\text { Bergstadt Bleiberg e.V. } \\
\text { Bleiberg, Sachsen }\end{array}$ & & $\begin{array}{l}\text { Medieval } \\
\text { settlement }\end{array}$ & & \\
\hline 53 & $\begin{array}{l}\text { Goldkuppe } \\
\text { Diesbar-Seußlitz, } \\
\text { Sachsen }\end{array}$ & $\begin{array}{l}\text { arch. site made } \\
\text { accessible }\end{array}$ & & & \\
\hline \multirow[t]{2}{*}{54} & $\begin{array}{l}\text { Burg und Kloster } \\
\text { Oybin } \\
\text { Oybin, Sachsen }\end{array}$ & $\begin{array}{l}\text { arch. site made } \\
\text { accessible }\end{array}$ & & & \\
\hline & \multicolumn{5}{|l|}{ BADEN-WÜRTTEMBERG } \\
\hline 55 & $\begin{array}{l}\text { Limesmuseum } \\
\text { Aalen, Baden- } \\
\text { Württemberg, }\end{array}$ & $\begin{array}{l}\text { arch. site made } \\
\text { accessible }\end{array}$ & $\begin{array}{l}\text { Roman } \\
\text { fortification }\end{array}$ & & \\
\hline
\end{tabular}




\begin{tabular}{|c|c|c|c|c|c|}
\hline & \multirow{2}{*}{$\begin{array}{c}\text { Quality } \\
\text { Locality and object }\end{array}$} & \multicolumn{2}{|c|}{ 1. authentic } & \multicolumn{2}{|c|}{ 2. fictitious } \\
\hline & & $\begin{array}{l}\text { a. original } \\
\text { site in situ }\end{array}$ & $\begin{array}{c}\mathrm{b} . \\
\text { reconstructed }\end{array}$ & $\begin{array}{c}\text { a. } \\
\text { scientifically } \\
\text { proven }\end{array}$ & $\begin{array}{c}\text { b. } \\
\text { scientifically } \\
\text { inspired }\end{array}$ \\
\hline 56 & $\begin{array}{l}\text { Keltisches Oppidum } \\
\text { Altenburg, Baden- } \\
\text { Württemberg }\end{array}$ & $\begin{array}{l}\text { arch. site made } \\
\text { accessible }\end{array}$ & $\begin{array}{l}\text { Reconstructed } \\
\text { parts of a } \\
\text { Celtic oppidum }\end{array}$ & & \\
\hline 57 & $\begin{array}{l}\text { Römerbadruine } \\
\text { Badenweiler } \\
\text { Badenweiler, } \\
\text { Baden-Württemberg }\end{array}$ & $\begin{array}{l}\text { arch. site made } \\
\text { accessible }\end{array}$ & & & \\
\hline 58 & $\begin{array}{l}\text { Federsee-Museum und } \\
\text { ArchäoPark Federsee } \\
\text { Bad Buchau, Baden- } \\
\text { Württemberg }\end{array}$ & & $\begin{array}{l}\text { Neolithic } \\
\text { settlement }\end{array}$ & & \\
\hline 59 & $\begin{array}{l}\text { Keltenmuseum } \\
\text { Hochdorf-Enz } \\
\quad \text { Eberdingen- } \\
\text { Hochdorf, Baden- } \\
\text { Württemberg }\end{array}$ & $\begin{array}{l}\text { arch. site made } \\
\text { accessible }\end{array}$ & $\begin{array}{l}\text { Celtic } \\
\text { buildings }\end{array}$ & & \\
\hline 60 & $\begin{array}{l}\text { Römisches } \\
\text { Freilichtmuseum } \\
\text { Hechingen-Stein } \\
\text { Hechingen-Stein, } \\
\text { Baden-Württemberg }\end{array}$ & $\begin{array}{l}\text { arch. site made } \\
\text { accessible }\end{array}$ & $\begin{array}{l}\text { Romain villa } \\
\text { rustica }\end{array}$ & & \\
\hline 61 & $\begin{array}{l}\text { Heuneburgmuseum } \\
\quad \text { Herbertingen- } \\
\text { Hundersingen, Baden- } \\
\text { Württemberg }\end{array}$ & $\begin{array}{l}\text { arch. site made } \\
\text { accessible }\end{array}$ & $\begin{array}{l}\text { Celtic prince's } \\
\text { seat }\end{array}$ & & \\
\hline 62 & $\begin{array}{l}\text { Freilichtmuseum } \\
\text { Römerbad } \\
\text { Jagsthausen, Baden- } \\
\text { Württemberg }\end{array}$ & $\begin{array}{l}\text { arch. site made } \\
\text { accessible }\end{array}$ & & & \\
\hline 63 & $\begin{array}{l}\text { Pfahlbaumuseum } \\
\text { Unteruhldingen } \\
\text { Unteruhldingen, } \\
\text { Baden-Württemberg }\end{array}$ & & $\begin{array}{l}\text { prehistoric } \\
\text { lake dwellings }\end{array}$ & & \\
\hline & BAVARIA & & & & \\
\hline 64 & $\begin{array}{l}\text { Fränkisches } \\
\text { Freilandmuseum } \\
\text { Bad Windsheim, } \\
\text { Bayern }\end{array}$ & & $\begin{array}{l}\text { Medieval } \\
\text { buildings }\end{array}$ & & \\
\hline 65 & $\begin{array}{l}\text { Hersching am } \\
\text { Ammersee, Bayern }\end{array}$ & & $\begin{array}{l}\text { early Medieval } \\
\text { temple }\end{array}$ & & \\
\hline 66 & $\begin{array}{l}\text { Archäologischer Park } \\
\text { Cambodunum } \\
\text { Kempten, Bayern }\end{array}$ & $\begin{array}{l}\text { arch. site made } \\
\text { accessible }\end{array}$ & $\begin{array}{l}\text { Roman temple } \\
\text { area }\end{array}$ & & \\
\hline 67 & $\begin{array}{l}\text { Mammutheum } \\
\text { Scharam/Alzing, } \\
\text { Bayern }\end{array}$ & & Stone Age park & & \\
\hline 68 & $\begin{array}{c}\text { Keltendorf Gabreta } \\
\text { Ringelai, Bayern }\end{array}$ & & $\begin{array}{l}\text { Celtic } \\
\text { settlement and } \\
\text { fields }\end{array}$ & & \\
\hline
\end{tabular}




\begin{tabular}{|l|l|l|l|l|l|}
\hline & \multicolumn{1}{|c|}{ Quality } & \multicolumn{2}{|c|}{ 1. authentic } & \multicolumn{2}{c|}{ 2. fictitious } \\
\hline & Locality and object & $\begin{array}{c}\text { a. original } \\
\text { site in situ }\end{array}$ & $\begin{array}{c}\text { b. } \\
\text { reconstructed }\end{array}$ & $\begin{array}{c}\text { a. } \\
\text { scientifically } \\
\text { proven }\end{array}$ & $\begin{array}{c}\text { b. } \\
\text { scientifically } \\
\text { inspired }\end{array}$ \\
\hline 69 & $\begin{array}{l}\text { SWITZERLAND } \\
\text { Augst, Schweiz, }\end{array}$ & $\begin{array}{l}\text { arch. site made } \\
\text { accessible }\end{array}$ & $\begin{array}{l}\text { Roman } \\
\text { settlement }\end{array}$ & & \\
\hline
\end{tabular}




\section{Appendix 2.}

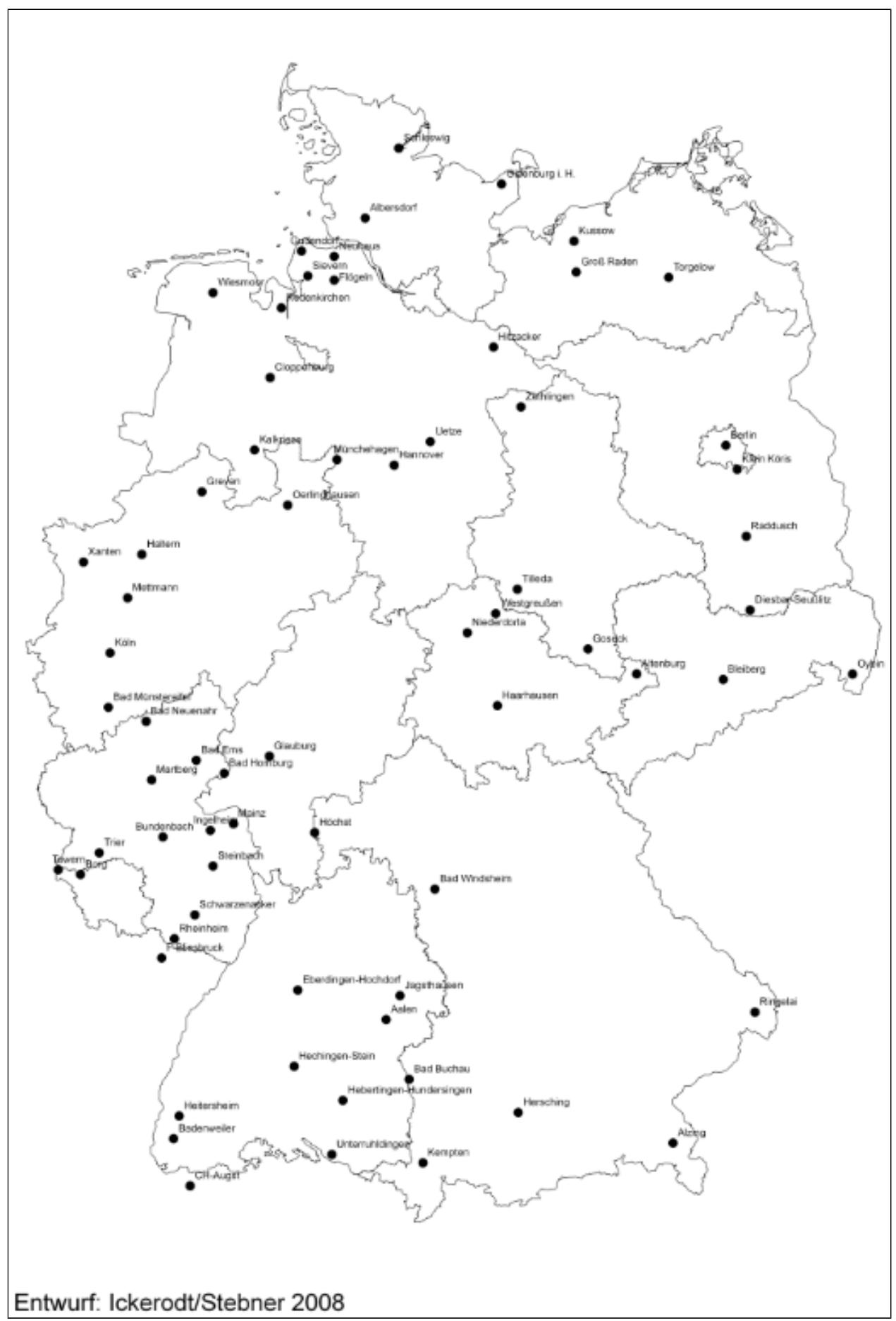

Map of localities listed in Table 1: archaeological sites, open-air museums and leisure parks as places where history is imparted to the public (Draft \& map U. Ickerodt, L. Stebner). 


\section{Appendix 3.}

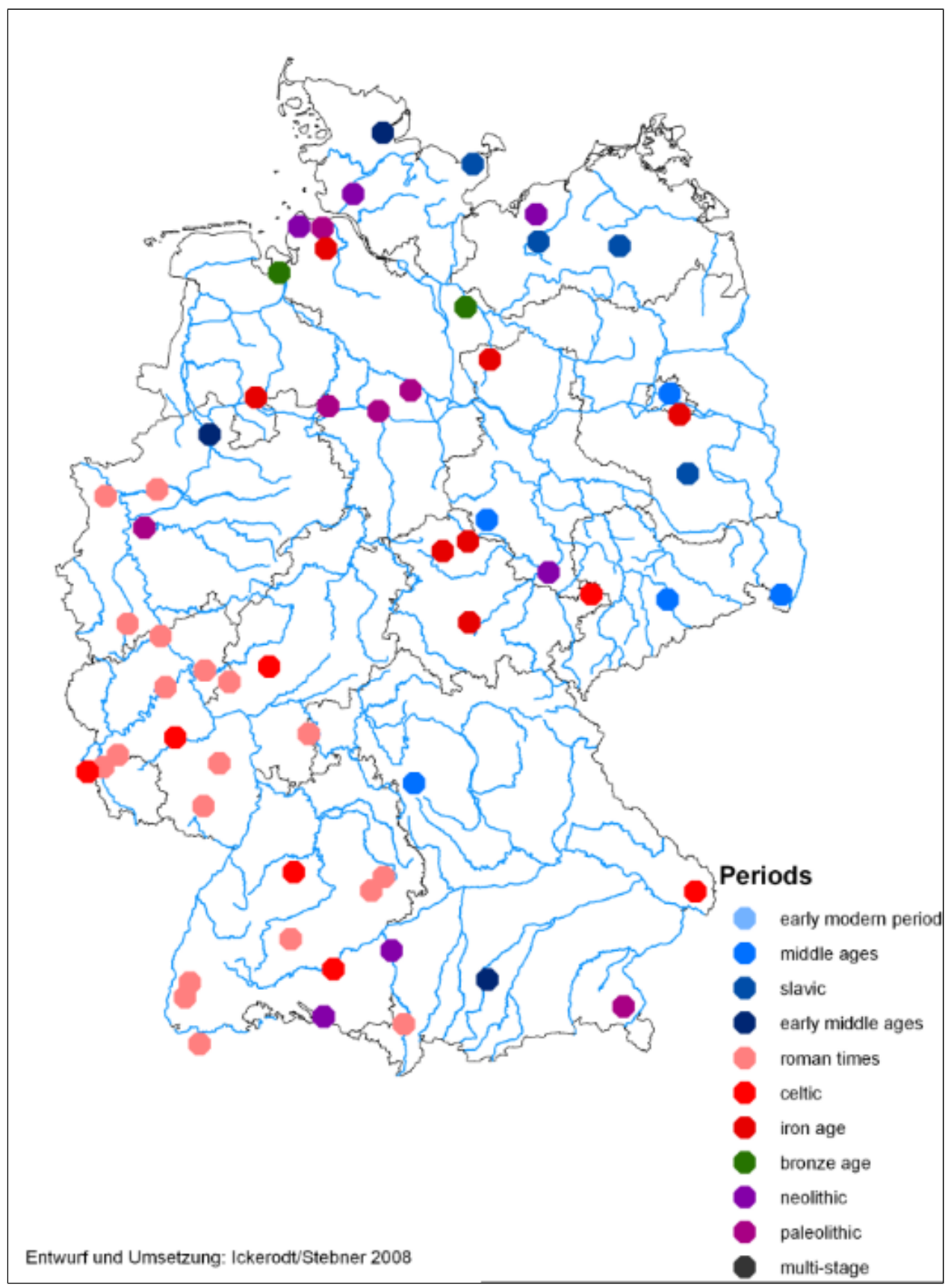

Map of localities listed in Table 1 maped in relation to the period they reflect. 